NBER WORKING PAPER SERIES

\title{
CRIMES AGAINST MORALITY: UNINTENDED CONSEQUENCES OF CRIMINALIZING SEX WORK
}

\author{
Lisa Cameron \\ Jennifer Seager \\ Manisha Shah \\ Working Paper 27846 \\ http://www.nber.org/papers/w27846 \\ NATIONAL BUREAU OF ECONOMIC RESEARCH \\ 1050 Massachusetts Avenue \\ Cambridge, MA 02138 \\ September 2020
}

We would like to thank participants at Dartmouth, CU Denver, George Washington University, LSE, Princeton, PUC-Rio, UC Irvine, USC, University of Virginia, Australian National University, UNSW, and APPAM for their valuable comments and feedback, as well as Gabriela Rubio for excellent research assistance. We gratefully acknowledge funding for this project from the Australian Research Council and Abdul Latif Jameel Poverty Action Lab Southeast Asia (JPAL SEA). Shah's work was also supported by the Center for HIV Identification, Prevention, and Treatment (CHIPTS) NIMH grant P30 MH058107-21. Data for this project was collected in partnership with SurveyMETER who we thank for their many invaluable suggestions in the field. For questions or comments please contact Manisha Shah at ManishaShah@ucla.edu The views expressed herein are those of the authors and do not necessarily reflect the views of the National Bureau of Economic Research.

NBER working papers are circulated for discussion and comment purposes. They have not been peer-reviewed or been subject to the review by the NBER Board of Directors that accompanies official NBER publications.

(C) 2020 by Lisa Cameron, Jennifer Seager, and Manisha Shah. All rights reserved. Short sections of text, not to exceed two paragraphs, may be quoted without explicit permission provided that full credit, including $\odot$ notice, is given to the source. 
Crimes Against Morality: Unintended Consequences of Criminalizing Sex Work

Lisa Cameron, Jennifer Seager, and Manisha Shah

NBER Working Paper No. 27846

September 2020

JEL No. I18,J16,K42

\begin{abstract}
$\underline{\text { ABSTRACT }}$
We examine the impact of criminalizing sex work, exploiting an event in which local officials unexpectedly criminalized sex work in one district in East Java, Indonesia, but not in neighboring districts. We collect data from female sex workers and their clients before and after the change. We find that criminalization increases sexually transmitted infections among female sex workers by 58 percent, measured by biological tests. This is driven by decreased condom access and use. We also find evidence that criminalization decreases earnings among women who left sex work due to criminalization, and decreases their ability to meet their children's school expenses while increasing the likelihood that children begin working to supplement household income. While criminalization has the potential to improve population STI outcomes if the market shrinks permanently, we show that five years post-criminalization the market has rebounded and the probability of STI transmission within the general population is likely to have increased.
\end{abstract}

Lisa Cameron

Melbourne Institute:

Applied Economic and Social Research

Level 5, FBE Building

111 Barry St

University of Melbourne

VIC 3010, Australia

lisa.cameron@unimelb.edu.au

Jennifer Seager

Department of Global Health

George Washington University

Milken Institute School of Public Health

950 New Hampshire Ave, NW, 4th Floor

Washington, DC 20052

jseagermuz@gwu.edu
Manisha Shah

Department of Public Policy

University of California, Los Angeles

Luskin School of Public Affairs

3250 Public Affairs Building

Los Angeles, CA 90095-1656

and NBER

manishashah@ucla.edu

A online appendix is available at http://www.nber.org/data-appendix/w27846 


\section{Introduction}

The regulation of sex work is a hotly debated issue in both low and high-income countries, and sex work persists with varying degrees of legality around the world (Farmer and Horowitz, 2013). In 2015, Amnesty International brought this debate into the spotlight by passing a resolution calling for the decriminalization of sex work, arguing that decriminalization is the best way to defend sex workers' human rights against violations such as exclusion from health care (Amnesty International, 2015). A Lancet series claims that decriminalizing sex work would have the greatest effect on the course of HIV epidemics across all settings, averting 33-46 percent of HIV infections in the next decade (Lancet, 2015).

Despite these claims, causal empirical evidence on the impacts of regulating sex markets is sparse, particularly from lower income countries. This paper presents new causal evidence on the impact of criminalizing sex work in a lower income country on the spread of sexually transmitted infections (STIs) by exploiting a natural experiment in which commercial sex work was unexpectedly criminalized in one district in East Java, Indonesia, while it remained non-criminalized in neighboring districts. ${ }^{1}$ We apply a difference-in-differences framework to a panel dataset we collected from sex workers in East Java at both criminalized and noncriminalized worksites, before the criminalization was anticipated and after the criminalization occurred. We also collected data on a representative sample of clients at all study locations before and after criminalization, which we use to corroborate the main findings.

The headline finding is that criminalizing sex work increases STI rates among sex workers (measured using biological test results) by 27.3 percentage points, or 58 percent, from baseline.

\footnotetext{
${ }^{1}$ Most of the literature related to regulation of sex work in lower-income countries has focused on occupational licensing requirements (see for example Gertler and Shah [2011]; Manian [2018]; Ito, Lépine and Treibich [2018]).
} 
Using data from both clients and sex workers, we show that the main mechanism driving the increase in STI rates is a decrease in access to condoms, an increase in condom prices, and an increase in non-condom sex. Sex workers are more than 50 percentage points less likely to be able to produce a condom when asked by survey enumerators at endline, and clients report a 61 percentage point increase in non-condom sex.

We also examine the economic consequences for the women and their children. Criminalization of sex work is often designed to force women out of sex work and shut down the sex market. Using data obtained from tracking women who left sex work post-criminalization, we show that those who leave sex work because of criminalization have lower earnings than those who leave by choice. In addition, children of women from criminalized worksites are adversely affected - they have less money for school and are more likely to work in order to supplement household income.

The health consequences of criminalization are not restricted to sex workers. While the size of the sex market decreases in the short run, reducing the probability of STI transmission, additional data collected five years post-criminalization show that the market rebounds, with the total number of sex workers being similar to prior to criminalization. In the longer-term, our calculations suggest that criminalization results in substantial increases in the probability of STI transmission to the general population. Depending on the counterfactual, the transmission probability under criminalization five years later ranges between 22 and 59.3 percent higher for males and between 13.6 and 48.3 percent higher for non-sex worker females compared to if sex work had not been criminalized in this district. Therefore, the long-run public health impacts of criminalization, in a country like Indonesia with already high rates of HIV and a population 
with limited access to testing and medication, are potentially alarming.

Understanding the impacts of criminalization (or decriminalization) on sex markets in lowerincome countries is arguably even more important than in higher-income nations. First, sex work has been a key driver of the HIV epidemic in lower-income countries (Kharsany and Karim, 2016). In Indonesia, HIV prevalence among female sex workers is estimated to be 9 percent-38 times higher among sex workers than the general female population. In addition, there is substantial variation across the country, with the highest HIV prevalence being 56 percent among female sex workers in the central highlands of Papua (Indonesia National AIDS Commission, 2014). ${ }^{2}$ Second, relatively more women in lower-income countries participate in sex markets. Female sex worker prevalence (defined as the proportion of female sex workers in the adult female population 15-49 years) ranges between 0.7-4.3 percent in sub-Saharan Africa, 0.2-2.6 percent in Asia, and 0.2-7.4 percent in Latin America, compared to only 0.11.4 percent in Western Europe (Vandepitte et al., 2006). Lastly, coupling these elements with lower-incomes, less education and, hence, less health knowledge alongside a less developed health care system means that changes in sex worker HIV and STI rates due to market changes may have larger public health implications in lower-income countries. It is thus critical to understand the magnitudes of the impacts of such policies when applied in these settings.

A further contribution of the paper is that it studies criminalization rather than decriminalization. While there is some recent causal evidence of the impact of decriminalizing sex work on sex worker and general population health in high-income countries (see for example, Bisschop,

\footnotetext{
${ }^{2}$ While Indonesia has some of the highest HIV rates among sex workers in Asia (relative to rates of 2 percent among sex workers in India and Thailand (Thai National AIDS Commission, 2014; National AIDS Control Organisation, 2018), it is still lower than sex worker HIV prevalence in Sub-Saharan Africa which was estimated at 30.7 percent (Kharsany and Karim, 2016). Rates of STIs (e.g., gonorrhea, chlamydia, and syphilis) in Indonesia are reported to be the highest among Asian countries (Kendall and Razli, 2010; Magnani et al., 2010).
} 
Kastoryano and van der Klaauw [2017]; Cunningham and Shah [2018]; Nguyen [2016]), there is little evidence — anywhere — of the impact of the opposite phenomenon—criminalization of sex work when sex work was previously 'legal'. It is unclear whether impacts of criminalization and decriminalization are likely to be symmetrical. The behavior and choices of women who leave sex work as a result of criminalization will have been shaped by their experience in sex work and their opportunities likely curtailed by the stigma associated with having been a sex worker. Ciacci (2019) studies the Swedish sex market where the demand side of the market (male buyers) is criminalized and finds that criminalizing demand increases rape in the general population. Other, largely qualitative, evidence on the impacts of the Swedish law suggest that street sex work decreased immediately after the laws were introduced but has since returned (Levy and Jakobsson, 2014; Dodillet and Ostergren, 2011). Criminalization in Indonesia, in contrast, largely targeted the supply side of the market by closing formal establishments and targeting women, so provides an interesting counterpoint to the Swedish experience. However, like Sweden, we also find that the market rebounds in the longer-term.

\section{Context and Study Site}

The study area encompasses the districts of Malang, Pasuruan, and Batu in East Java, Indonesia (see Figure I). East Java is a densely-populated province with a population of almost 40 million, with the study area accounting for approximately 4.5 million people. As is common throughout Indonesia, sex work in East Java occurs in both formal worksites (i.e., brothels) and informal worksites (i.e., the street).

Formal worksites are recognized centers where sex workers live and work and pay fees to 
cover the cost of electricity, water, security, etc. and are required to have monthly health and STI checks. NGOs and the local Ministry of Health often coordinate outreach at these worksites to promote safe sex practices and provide free condoms. In contrast, informal worksites are located alongside railway lines, at local markets, or in neighborhoods near the homes of the informal sex workers. There are no health check requirements, and no services are provided to these women. The informal worksites tend to be smaller than formal worksites (seven sex workers per site on average compared to fifty-five at formal worksites).

We mapped the universe of formal and informal worksites in these districts in collaboration with a community-based organization already working with the sex worker population. Of the 17 worksites included in the study, nine are in Malang (six of which are formal and become criminalized) and eight are in the neighboring districts of Pasuruan and Batu (four of which are formal).

\section{II.A Worksite Closure}

Sex work is not directly addressed in Indonesian national law. As a result, sex work is widespread and largely tolerated throughout Indonesia, including East Java. However, a section of law titled "Crimes Against Morals" can be read to apply to sex work and has been used by local officials in some areas to close down sex worksites. On July 11, 2014, the Malang District government announced that on November 28, 2014, it would close all formal sex worksites within the district as a "birthday present" to Malang (Sukarelawati, 2014). The closures aligned with anniversary celebrations in Malang District and had religious overtones, being justified on the basis of sex work being banned by all religions (Tribunews.com, 2014). The centers were to reopen for different, legal activities, like karaoke bars. However, no budget was allocated to the 
transition of these sites away from sex work (Malang Post, 2014).

The announcement of the worksite closures was unanticipated. To the best of our knowledge, when we conducted baseline surveys in February-March 2014 there was no expectation of the closures. In fact, we had considered conducting the research (which was originally planned to be a randomized controlled trial offering micro-savings products to sex workers) in Surabaya but had been advised by the community-based organization that we were working with, whose main mission is to work with sex workers in the Malang area, that worksite closures were possible in Surabaya. We specifically selected Malang as our study site because worksite closures were not anticipated.

Management at formal worksites was directed not to accept any new sex workers after the end of the Islamic holy month of Ramadan (July 28, 2014). The closures were enforced by police raids after the criminalization date of November 28, 2014 (Bupati Merasa Ditelikung Pengelola Eks Lokalisasi, 2014), as confirmed by qualitative fieldwork conducted in January and February 2015. This fieldwork also found that the sex market continued to operate in these locations, but the activities became more underground and quiet. The local health ministry stopped conducting regular health exams and providing free condoms at the formal worksites in Malang (RCA, 2016).

Sex work at informal sites in Malang and at formal sites in Pasuruan and Batu continued, unaffected by the Malang government's decree to criminalize formal worksites. The word criminalization translates to kriminalisasi in Indonesian. Kriminalisasi however implies that authorities are actively pursuing people who contravene the specific law or regulation through the court system. This is not the case in relation to the criminalization of sex work at our study 
site in East Java. Rather, enforcement is occurring through police raids and penalties.

Both Batu and Pasuruan border the district of Malang and are part of the Greater Malang area, making them ideal non-criminalized control sites (see Figure I). The entire sample is concentrated within an approximately 25 -mile radius.

\section{Data Collection and Summary Statistics}

Figure II illustrates the timing of data collection and worksite closures. We collected census data four times, each time attempting to capture the total number of sex workers at every site- - first in January-February 2014 (pre-criminalization), then in September 2014 (post-announcement but still pre-criminalization), then in February-March 2015 (post-criminalization), and finally in October 2019 (five years post-criminalization). As part of the earlier study (that was abandoned due to the criminalization), we conducted a baseline survey during February-March 2014 (prior to the announcement or expectation of the closures), seeking to survey all sex workers identified at formal and informal worksites in the first census. ${ }^{3}$ We also surveyed a sample of clients across the worksites, with the distribution of clients across the worksites being proportional to the size of the worksites. We collected data on 505 sex workers and 300 clients prior to criminalization, covering worksites that were and were not affected by the criminalization. Our sample consists of female sex workers and male clients, as this is the predominant form of sex work in these locations and in much of the world. In addition to collecting data among sex workers and clients, we also conducted surveys with men and women living in neighborhoods

\footnotetext{
${ }^{3}$ The initial census in January-February 2014 identified 605 sex workers. Thirty-three of these women were reported to have left sex work by the time of the baseline survey in February-March 2014. Of the 572 women who were still in sex work, 505 (88 percent) were interviewed. Of those who were not surveyed, eight refused, thirty-four women had moved home, four were sick, and we were unable to find twenty-one.
} 
near worksites in Malang, which we discuss in more detail in section VII.B.

We have as close to the population of female sex workers in greater Malang at formal and informal worksites as is possible, before and after the criminalization. We obtained this by working with a community-based organization that worked closely with sex workers in Malang and was knowledgeable about all sex worksites in the area. At baseline, we spent several days at each of the worksites and interviewed all workers at the sites. We also asked a worksite representative about the number of workers at the sites. There is nevertheless always some concern about missing and undercounting these types of hidden populations. The women we were most likely to miss in the surveys are the more informal and irregular sex workers who only occasionally sell sex.

To construct the sample of clients, we conducted interviews with clients who were at worksites at the time of the baseline surveys with sex workers. Clients often hang out at the worksites chatting with the women or having a drink or smoke. We approached them for interview at these times, with assurances of confidentiality. While we collected contact information from the sex workers so that we could follow them over time, we did not collect such information from clients.

Criminalization of formal worksites in Malang occurred on November 28, 2014. To examine the impact of the criminalization, we revisited the sites in May-June 2015 (approximately 15 months after baseline) for an endline survey. We again spent several days at each worksite, interviewing all women we found working and a sample of clients. We used the contact information provided at baseline to follow-up with sex workers interviewed previously, and surveyed any new sex workers who were found at the worksites during the census in February- 
March 2015 and at the time of endline. We surveyed 198 women in person who were still in sex work at endline, 144 of whom were also surveyed at baseline, which comprises the main endline sample that we use to analyze the impact of criminalization. However, this is only a subset of our endline data on the sex workers, which we discuss in more detail in the next paragraph. Since we did not collect contact information from clients at baseline, we do not have a panel of clients. Data from a new sample of 293 clients at endline was collected, again distributed across worksites proportional to worksite size.

We located approximately 70 percent of baseline sex workers at endline either in person, by phone, or via an informant (typically someone at the worksite who knew of the individual's current activities). ${ }^{4}$ We conducted follow-up surveys with those we contacted regardless of whether they were still working in sex work. Collecting panel data on sex workers is difficult given the high mobility of women in this profession. Tracking the women across time, particularly those who have left sex work, is especially challenging. The attrition rate of 31 percent compares well to other surveys of highly mobile populations. For example, the well-respected IZA-supported Longitudinal Survey on Rural Urban Migration in China (RuMiC) had attrition rates among urban migrants of 64,52 , and 43 percent across successive waves. ${ }^{5}$ Importantly, our attrition rate is similar across criminalized worksites (31 percent); non-criminalized formal worksites (29 percent), and non-criminalized informal worksites (33 percent). Figure I.I and Table I.I in the Appendix provide details of the sample composition. In section VI.C, we closely examine sample attrition and show that it is not driving the results.

\footnotetext{
${ }^{4} \mathrm{We}$ interviewed 75 women at endline by phone. Only 13 of these women reported that they were still in sex work. As we only collect information on a subset of variables for these women, we do not include these observations in our main analysis. Doing so however does not affect the results. We do include data from the phone surveys in our analysis of earnings, well-being and children's outcomes in Table V.

${ }^{5} \mathrm{See}$ https://datasets.iza.org/dataset/58/longitudinal-survey-on-rural-urban-migration-in-china
} 
The baseline and endline surveys of sex workers collected information on demographics, employment and income, details of commercial sex transactions and characteristics of clients, HIV/STI knowledge, risk and time preferences. The client surveys collected a similar array of information. We use the client data to corroborate reports by sex workers of condom use and other transaction characteristics. ${ }^{6}$ To eliminate concerns about reporting bias of STI symptoms, we also collected biological test results from vaginal swabs. These were collected in September 2014 (baseline) and September 2015 (endline). Details of the data collection process, the phone and informant surveys and the biological testing are provided in the Appendix sections I.A and I.B.

Table I presents summary statistics of sex worker and client characteristics at baseline. Panel A shows that the average sex worker in our sample is approximately 35 years of age, has five to six years of education, is divorced (or widowed), and has children. Tests of differences in means show no significant differences in these characteristics across the criminalized and noncriminalized sites. There are, however, differences in some of the outcome measures (see Panel B). Health exams and condom use were more common at criminalized sites and STI prevalence was lower. Table I, Panel C shows a similar pattern for clients across criminalized and noncriminalized worksites, where clients have similar demographic characteristics but are more likely to report using condoms at criminalized worksites at baseline. These differences may reflect that the criminalized sites in Malang were more tightly organized than in Pasuruan/Batu prior to criminalization.

\footnotetext{
${ }^{6}$ There are only a small number of studies which have collected quantitative data on sex worker clients. Pitpitan et al. (2014) is one such example and provides references for others. The collection of longitudinal data on sex workers is also rare, particularly in a developing country setting. Such data have been collected in India (Ghosal et al., 2016), in Senegal (Lyons et al., 2017), and there are a series of papers utilizing such data from Mexico (for example, Patterson et al. (2008) and Vera et al. (2012)). None of these studies have examined the impacts associated with sex work criminalization or decriminalization.
} 
In Table I.II in the Appendix we compare sex workers in our sample to general population women. Sex workers have less education (5.8 years of education versus 7.5 years) and are much more likely to be divorced or widowed (76 percent versus 16 percent), but have a similar probability of having children (90 percent versus 93 percent). ${ }^{7}$

In October 2019, five years after criminalization, we conducted another count of sex workers at all the worksites in Malang, Pasuruan and Batu. We use these numbers to understand the longer-term impacts of criminalization on public health outcomes.

\section{Impact of Criminalization on the Size of the Market}

We first check whether criminalization impacted the size of the sex market in Malang. As criminalization increases the costs associated with commercial sex work, effectively increasing the barrier to entry into the market, we expect a decrease in the number of sex workers and clients at the affected worksites (Lee and Persson, 2015).

Figure III shows the changes in the population of sex workers between each point in FebruaryMarch 2014 (pre-criminalization), September 2014 (pre-criminalization but post-announcement), May-June 2015 (post-criminalization), and October 2019 (approximately five years after criminalization). It shows a modest decrease in all worksite populations from February-March 2014 to September 2014. From September 2014 to May-June 2015 (following the closures), the sex worker population at the criminalized worksites decreases by around 50 percent, while the populations at the non-criminalized worksites remain stable.

The figure also shows that sex workers do not move from the criminalized worksites in

\footnotetext{
${ }^{7}$ These estimates are calculated from comparisons using the 2013 National Socio-Economic Survey (Susenas) data for Malang, Pasuruan and Batu (see Table I.II).
} 
Malang to the non-criminalized worksites in the surrounding areas, as we do not see increases in sex worker populations at non-criminalized worksites (at least in the short-run). That there is very little switching of women across worksites is clear from our conversations with the women on site and from our quantitative work. In our endline survey, we ask sex workers if they moved locations and where they moved. We observe no location switching among sex workers we interviewed in person or among women that we surveyed by phone. In the informant surveys, of 82 women who were reported to be still in sex work, four had moved from a formal worksite to an informal worksite. Out of the 454 women that we tracked, this means that only 1 percent moved between formal and informal locations. The informal sites in and around Malang attract a different type of worker, and this type of street work is not considered by most women who have been working at the formal sites. Table I.III in the Appendix presents a comparison of the characteristics of sex workers and clients at formal and informal sites. It shows that the clients at the informal sites are less well-educated, more risk-loving, and that the sex workers are older (possibly reflecting they have fewer options). The women are also less likely to report attending a health exam, are less likely to have a condom, and less likely to report having used one.

Figure III also shows the size of the market in the longer run (five years post-criminalization). It shows that the market reverts to its original total size. The criminalized worksites grow about 63 percent but do not reach baseline levels. However, non-criminalized areas grow significantly more, by around 175 percent. 


\section{Empirical Framework and Main Results}

We use a difference-in-differences (DD) strategy to analyze the impact of criminalizing formal worksites in Malang, comparing changes at the criminalized worksites from baseline to endline with those at the non-criminalized sites. We use all non-criminalized worksites as the control group but also estimate all regressions using only formal non-criminalized worksites as the control group, and the results are qualitatively similar (see Tables I.IV and I.V in the Appendix). ${ }^{8}$

The main specification used in the analysis is:

$$
Y_{i s t}=\beta_{1} \text { Crim }_{s} \times \text { Post }_{t}+\beta_{2} \text { Post }_{t}+X_{i s t} \xi+\alpha_{1} S_{s}+\epsilon_{i s t}
$$

where $Y_{i s t}$ is the outcome of interest for sex worker or client $i$ at worksite $s$ in time $t$ (e.g. probability of having an STI; condom use; access to health exams; sex work activities; etc.); $\mathrm{Crim}_{s}$ equals 1 if worksite $s$ is a site where sex work was criminalized, 0 otherwise; Post equals 1 for the period after the criminalization, 0 otherwise; and $\epsilon_{i s t}$ is the error term. $\beta_{1}$ is the DD estimate of the impact of criminalization, which is reported in the tables. Standard errors are clustered at the worksite level. Since we have at most 17 clusters (worksites) in our analysis - six treatment clusters and eleven control clusters - we employ the wild clusterbootstrap percentile-t procedure (Cameron, Gelbach and Miller, 2008) to estimate appropriate $\mathrm{p}$-values for the main coefficient of interest, $\beta_{1}$.

For the regressions using the sex worker data, $X_{i s t}$ is a vector of covariates that includes

\footnotetext{
${ }^{8}$ We do not expect there to be impacts on the informal sites as they were not subject to criminalization. The small number of informal sex workers in our sample precludes us from investigating the impacts of criminalization of the formal sites in Malang on the informal sites in Malang for many of our key variables, including STI prevalence. For variables where we do have sufficient observations to allow such a comparison, e.g. condom use, we find no significant impacts.
} 
individual controls for marital status, age, years of education, whether the sex worker has children, the number of years the sex worker has worked at the worksite, an estimated discount factor based on a hypothetical scenario to elicit time preferences, and an indicator for risk tolerance based on a risk game with monetary rewards (see details of the time preference and risk tolerance measures in Section II in the Appendix), and $S_{s}$ is a set of worksite fixed effects. For the regressions using the client level data, $X_{i s t}$ is the same but for clients and excludes the variables for having children and the number of years at the worksite, and $S_{s}$ is a set of district (Malang, Pasuruan, Batu) by worksite type (formal, informal) fixed effects. ${ }^{9}$

For analysis using the transaction-level data on risky sexual behaviors (e.g., non-condom use) with multiple observations per sex worker or client, we include a full set of individuallevel fixed effects instead of worksite fixed effects and cluster standard errors at the worksite level.

While there were some differences between criminalized and non-criminalized sites prior to criminalization, baseline balance is not required for the DD identification strategy. The key identifying assumption for equation (1) is that the outcomes of interest in Malang would not have evolved differently to the outcomes in Pasuruan and Batu in the absence of criminalization. Ideally, we would have data on the sex worker outcomes of interest for at least two years prior to 2014 to test this assumption; unfortunately, these data are not available. We are, however, able to use data from the National Socio-economic Survey (Survei Sosial Ekonomi Nasional, Susenas) for the years 2010-2013 to examine trends in related variables. The Susenas is a nationally representative annual survey of Indonesian households conducted by the Indonesian Statistical

\footnotetext{
${ }^{9}$ We do not include worksite fixed effects for the client regressions because clients can visit more than one worksite so including district by worksite type fixed effects is more appropriate. Specifications with worksite fixed effects, however, produce results consistent with those shown. Results available on request.
} 
Agency and includes information on condom use of married women, whether a woman experienced a health symptom in the previous month (as an indicator of women's health, including sexual health), female employment in the last week (as an indicator of women's empowerment), and earnings (as an indicator of economic trends). ${ }^{10}$ We restrict the sample to the districts in our sample and then randomly sample from twelve age/education bins so that the constructed sample has the same age/education profile as the sample of sex workers to be as close as possible to our survey sample. To test for differential trends we estimate the following equation:

$$
\begin{aligned}
Y_{i t}=\beta_{1} \text { Malang }_{i} & +\sum_{t=2010}^{2013} \beta_{2 t} \text { Malang }_{i} \times \text { year }_{t} \\
& +\sum_{t=2010}^{2013} \beta_{3 t} \text { year }_{t}+\epsilon_{i t},
\end{aligned}
$$

where $Y_{i t}$ is the variable whose trend we are examining; Malang $g_{i}$ is an indicator for being in the district in which sex work was criminalized; year ${ }_{t}$ is a vector of indicators for each year from 2010-2013. The coefficients of interest, $\beta_{2 t}$, take on a unique value for each year from 2010-2013 and pick up the differences between Malang and the other districts in each year. The base year is 2013 , the year prior to criminalization.

Figure IV plots the estimates $\left(\beta_{2 t}\right)$ and confidence intervals of the difference between Malang and Pasuruan/Batu for each outcome. It shows that there are no significant differences between trends in outcomes in Malang and Pasuruan/Batu pre-criminalization.

\footnotetext{
${ }^{10}$ For health symptoms we generate an indicator equal to 1 if a respondent reports experiencing any "other" health symptom in the last month. This category excludes common cold and flu symptoms (such as fever, cough, cold, headache), asthma, diarrhea, and toothache. "Other" health symptom is the category that captures STI symptoms.
} 


\section{V.A Impact of Criminalization on Sex Worker Health}

We now examine the impact of criminalization on the main outcome of interest—having a positive biological test result for STIs. Figure V presents the STI prevalence rates at criminalized and non-criminalized worksites at baseline and endline. It shows a marked increase in STI prevalence at worksites that were criminalized and no statistically significant change in STI prevalence at non-criminalized sites over the same period. Panel A of Table II presents results of $\beta_{1}$ from equation (1) using the full baseline and endline sample and Panel B presents results when restricted to the panel sample.

Sex workers are in the panel sample if they were interviewed at baseline and at endline and indicated that they are still engaged in sex work at endline. Women who are interviewed at endline but who no longer sell sex are excluded from the analysis in Table II because we were unable to collect biological exam data from women who left sex work at endline. We examine the consequences of this and sample attrition in detail below. ${ }^{11}$ Since the panel data results compare outcomes for the same women over time, we can be confident that changes in sex worker characteristics are not driving the results. Much of the decrease in sample size from baseline to the endline sample of women who are still engaging in sex work is not "sample attrition" in the traditional sense but reflects the shrinkage of the market in response to the policy change. ${ }^{12}$

\footnotetext{
${ }^{11}$ The STI prevalence among sex workers who leave sex work is of lesser importance from a public health perspective as these women will play a smaller role in the transmission of STIs compared to those who remain in sex work (Pruss-Ustun et al., 2013; UNAIDS and World Bank, 2010). Nevertheless, in Table I.VI in the Appendix we make a range of assumptions about the STI rates in the population of women who no longer sell sex and include them in our estimating sample. The results show that the point estimate for the impact of criminalization on STI prevalence remains positive even when we assume that the STI rate among women who left sex work is zero (though we lose statistical significance once the STI rate goes to 0 ).

${ }^{12}$ When examining outcomes related to sex work, e.g. STI prevalence, condom use, worksite operations and transaction data (Tables II, III, and IV), the sample used for estimation is sex workers who are still in sex work at endline. When examining outcomes not directly related to sex work, e.g. earnings, well-being, and child outcomes
} 
Column 1 of Table II indicates that criminalization increases the probability of a positive indicator for STIs by 27 percentage points (a 58 percent increase on the baseline mean of 46 percent). In Panel B, when we restrict to the panel sample, criminalization increases the probability of testing positive by 21 percentage points (61 percent). These results are robust to specifications without any controls (Appendix Table I.VII), to using only formal worksites as the control group (Appendix Table I.IV, Panels A and B), and to including individual fixed effects for the panel sample (Appendix Table I.IV, Panel C1 and C2).

\section{V.B Impact of Criminalization on Access to Health Exams and Condoms}

The increased prevalence of STIs among sex workers at the criminalized sites may reflect that sex work became more clandestine, raising barriers to the open promotion of condom use at these sites. For example, in one criminalized worksite, signs around the complex that read "Condoms must be used here" were changed to advertise karaoke activities post-criminalization. Reduced condom use is a potential mechanism for the observed increase in STI rates as condoms act as a protective barrier against STI transmission; for example, condoms are 80 percent effective against the transmission of bacterial STIs, such as gonorrhea and syphillis (Gertler, Shah and Bertozzi, 2005). It was also observed during fieldwork that criminalization decreased the ability of the worksites to organize visits to local health centers for health exams.

Columns 2-9 of Table II present evidence on the impact of criminalization on health exams, whether the sex worker reports that it is easy to obtain a condom at the worksite, whether the woman has a condom at the time of the survey, condom prices, an indicator of whether the sex worker reported that it is easy to ask clients to use a condom, and condom use (as (Table V), we use the entire sample of women and so include those who report having left sex work. 
reported by sex workers and clients). The estimated impacts of criminalization $\left(\beta_{1}\right)$ on the key outcome variables are also presented in Figure VI. The results show that women at criminalized sites are significantly less likely to be able to produce a condom on request by an enumerator, condoms are more expensive and less likely to be used (as reported by clients). Column 5 shows a 51.6 percentage point ( 58 percent) decrease in the probability of being able to produce a condom relative to non-criminalized sites. Condom prices increase by over 200 percent at criminalized sites relative to non-criminalized sites (column 6). This is consistent with reports in the qualitative work that NGOs and health workers no longer supplied low cost and free condoms to the criminalized worksites and that individuals from the sites had to travel to get condoms, charging women at the sites more for the condoms to cover travel costs. The point estimates on reports of whether it was easy to obtain condoms, easy to ask a client to use a condom, and condom use as reported by sex workers are also uniformly large and negative, though not statistically significant at conventional levels. Both sex workers (column 8) and clients (column 9) at criminalized sites report lower condom use in their last three commercial sex transactions post-criminalization (by 12 and 61 percentage points, respectively), although only the client reports are statistically significant. Following the method of Kling, Liebman and Katz (2007), we construct an unweighted index of condom use from the standardized variables in columns 4 to 7 and use it as the dependent variable in column 3. Criminalization has a significant and large negative effect on the condom use index of 0.87 standard deviations. The results are robust to excluding control variables (see Appendix Table I.VII), to using only formal worksites as the control group (see Appendix Table I.IV), and including individual fixed effects in the panel regressions (Appendix Table I.IV). 


\section{Alternative Mechanisms}

In this section we test for alternative mechanisms, aside from condom use, which could be

driving the increased STI rates. For example, women at criminalized worksites might have started seeing more clients or engaging in riskier forms of sex, in which case we might observe an increase in STIs independent of any decrease in access to condoms. Clients or sex workers changing behaviors in such a way as to become less willing to use a condom (e.g. becoming more risk-loving) could also explain the results. Finally, we test whether differential sample attrition could be driving the results.

\section{VI.A The Impact of Criminalization on Worksite Operations}

Columns 2-4 of the top two panels of Table III present estimates of the impact of criminalization on the number of clients the sex worker saw in the last seven days, the number of transactions she undertook in the last seven days, and the number of hours worked in the last seven days. These variables are all unaffected by criminalization. This is true for both the full and panel samples (Panels A and B). These sex worker reports are also corroborated by client reports. Columns 2 and 3 in Panel $\mathrm{C}$ of Table III present client reports of the number of sex workers they see and the number of transactions they engaged in over the past seven days. Again, the estimated coefficients on the interaction term between criminalization and post-criminalization are not statistically significant.

Thus it appears that although the number of sex workers and clients at the sites decreased with criminalization, the number of clients and transactions per sex worker remained approximately constant. Consistent with this, column 5 shows that there is no change in the price of 
a typical transaction (as reported by both clients and sex workers) and there is no change in weekly earnings (sex workers) or weekly expenditures on sex work (clients). These non-results are robust to various other samples, specifications, and to using only formal worksites as the control group (see Table I.V). The signs of the coefficients are consistent with the sex workers at the criminalized sites seeing more clients and engaging in more, shorter transactions (as hours worked decreases). During fieldwork women reported that they sometimes do not use condoms so as to be able to get through transactions more quickly. However, we generate an index that is the combination of columns $2,3,4$, and 6 , and there is no statistically significant impact of criminalization on this index (see column 1).

\section{VI.B Changes in Transaction, Sex Worker, and Client Characteristics}

We control for individual characteristics, including education, age, risk tolerance, and patience in the regression analysis. However, there might be some concern that the increased STI rates and reduced condom use are being driven by changes in the types of sex workers at the worksites, or clients frequenting the worksites, which may not be fully captured by the controls we include. For example, when sex work was decriminalized in Rhode Island, sex transactions became less risky and the new entrants had lower STI prevalence (Cunningham and Shah, 2018). This could be happening in Indonesia with post-criminalization transactions involving sex workers who are more willing to engage in risky behavior, though this cannot explain the results from the panel data as in those specifications we are comparing behavior of the same women across time.

Table IV presents the results when we test for changes in transaction type and sex worker and client characteristics. There is no evidence of a change in the type of activity that occurred 
during a transaction, measured by the probability of a transaction involving vaginal sex (as opposed to anal sex, oral sex, masturbation, and other forms of sexual activity). In general there is little variation in the sex acts performed with 97 percent of transactions involving vaginal sex. Moreover, there is no evidence of changes in client characteristics as reported by sex workers. Clients are less likely to report that a sex worker seemed clean, which could reflect the fact that sex workers are more likely to be infected with an STI as a result of worksite criminalization.

We also check for compositional changes in demographic characteristics (e.g., marital status, years of education, number of children, and years at the worksite location) and risk and time preferences of the sex worker and client populations. We find no evidence of compositional changes across these characteristics, with two exceptions. There is some evidence that sex workers at the criminalized sites are more educated (by 0.75 years) after criminalization occurs, relative to the non-criminalized sites. However, we find no evidence that sex worker education is associated with riskier sex in our sample (see column 1 of Table I.VIII in the Appendix). ${ }^{13}$ Similarly, there is evidence that clients at criminalized sites are younger after criminalization. Analysis of the relationship between age and condom use shows that younger clients are more likely to use a condom than older clients (see column 2 of Table I.VIII in the Appendix). Therefore, the small changes in composition toward younger clients, if anything, would bias us away from finding decreased condom use and increased prevalence of STIs among sex workers. We control for all of these observable characteristics in the regression analysis.

\footnotetext{
${ }^{13}$ Previous studies have found that more-educated sex workers are less likely to engage in risky sex practices (Gertler and Shah, 2011).
} 


\section{VI.C Sample Selection at Endline}

Although the results hold in the panel data and there is no evidence that sex workers in the endline sample are different (e.g., more risk-loving), this does not rule out the possibility that there is selection in relation to the types of women who leave the sample (or sex work), making the panel sample a selected sub-sample of sex workers that differs between criminalized and noncriminalized sites. We check for differential attrition across criminalized and non-criminalized worksites to test for whether the panel sample in criminalized sites is differentially selected on risky or "worse" characteristics.

There are three ways a woman from the baseline does not end up in the main endline analysis sample in Table II. Either we cannot locate her at endline, we can locate her but only via phone or informant—so no in-person survey/STI test is conducted—or we locate her and interview her in person, but she has left sex work. Women who left sex work were not STI tested at endline. Of the 348 women from baseline who we locate, we locate 158 in-person, 61 via phone, and 129 by informant. There is no statistically significant difference in the likelihood that we conduct a follow-up survey (in person, by phone, or informant) with a sex worker at criminalized and non-criminalized worksites (the difference in the resurvey rate is $0.01, p=$ 0.921). However, sex workers at criminalized worksites are less likely to have been surveyed in person (difference of $0.250, p<0.05$ ) and, conditional on conducting any follow-up survey, sex workers at criminalized worksites are more likely to have left sex work compared to sex workers at non-criminalized sites (difference of $0.259, p<0.01$ ). This means that sex workers at criminalized worksites are more likely to leave our "In Sex Work" sample (difference of $0.229, p<0.05$ ), which is the main analysis sample in this paper. However, this only affects the 
internal validity of our DD estimates if the women who left the analysis sample are substantively different from the women who stay and are different from the women who leave the analysis sample from non-criminalized sites, which we address in this section.

Figure VII presents the baseline means of our key outcome variables, tests positive, health exam, and the condom use index for those women who remain in the sample at endline and those who do not for criminalized and non-criminalized sites separately. ${ }^{14}$ The p-values in Figure VII show that the differences in these variables between attritors and those who remain in the sample are not statistically significant, with the exception of tests positive at criminalized sites. However, the direction of this difference (higher STI prevalence among those who left the sample in criminalized sites) would bias against finding that STI prevalence increased as a result of criminalization. Similarly, the direction of the differences in the condom use index at criminalized worksites bias against finding that condom access and use decreased with criminalization. The DD p-values in Figure VII show there is no statistically significant differential attrition for any of the outcomes of interest. Hence there is no evidence that sample attrition is driving the results.

Table I.IX in the Appendix reports results from additional tests for differential attrition by sector. We regress a dummy variable equal to one if the sex worker was interviewed at baseline but is not in the panel analysis sample on various socio-demographic characteristics and our outcome variables, interacted with criminalization. It shows little evidence of differential attrition.

\footnotetext{
${ }^{14}$ Table I.X in the Appendix presents the means underlying Figure VII.
} 


\section{Broader Impacts on Overall Population}

\section{VII.A Earnings, Happiness, and Children of Current and Past Sex Workers}

Among our sample, sex work is the primary source of income for the women. Therefore, criminalizing sex work has impacts not only on personal health, but also on earnings, which could impact happiness and the well-being of their dependent children. Most of the child-related outcomes were only collected in the endline survey, so here we compare women and children from criminalized worksites to non-criminalized worksites at endline (rather than estimating differences-in-differences). The results in Table $\mathrm{V}$ are suggestive that children under the age of 18 are being harmed by criminalization, as are women who are forced to leave sex work.

The majority of women (61 percent) who left sex work at the criminalized sites returned to their home village and 28 percent are not working (see Table I.I in the Appendix, which presents information on the location and work that women who left sex work are doing postcriminalization). Of those who left sex work and are working, 26 percent work in their own small business or a small shop and 32 percent work as a laborer. Forty-two percent are in another form of work-almost entirely in agriculture or small scale, low paid enterprises. In short, lucrative work opportunities are scarce for women who were formerly sex workers.

These observations are confirmed in Panel A of Table V, which compares earnings in the seven days prior to the endline survey of sex workers from criminalized worksites to those from non-criminalized worksites, by endline sex work status. The results show that women from criminalized worksites have lower weekly earnings at endline than those from non-criminalized worksites (column 2) and are more likely to report that their income is less-than-adequate to meet daily needs than women at non-criminalized worksites (column 3). Both of these results 
appear to be driven by women who left sex work at criminalized sites (Panel A3).

In terms of happiness, both current and past sex workers from criminalized worksites are more likely to report being very unhappy relative to their counterparts from non-criminalized worksites (see column 4 in Panel A of Table V). However, the standard errors are large and sample sizes are small.

In Panel B of Table V, we explore the association between criminalization and child-related outcomes. Sex workers from criminalized sites are significantly more likely to report that their children are affected by the closures, that they have less money for school expenses, and that their children began working to supplement income. Daughters of sex workers at criminalized sites are more likely to be affected and have less money to cover their school expenses than sons. Boys are more likely to have started working than girls.

\section{VII.B Health and Expenditure of Neighboring Population}

In addition to collecting data on sex workers and clients at the worksites in Malang, we also conducted household surveys with individuals living in the communities surrounding the worksites, at both baseline and endline. Data were collected in two neighborhoods that are near criminalized worksites and two neighborhoods that were farther away from criminalized worksites. A census was conducted in selected communities, and men and women were randomly selected for surveys based on pre-determined criteria so that their demographics are similar to those of the sex workers and clients. Women, aged 26-45 with similar education levels as sex workers, were sampled from four strata defined by marital status (never married, married, divorced, widowed) proportional to the distribution of sex workers in each of those categories. Men, aged 18-55 with similar education levels as clients, were sampled from five strata defined 
by employment industry (driver, entrepreneur, farm worker, salesman, and non-farm worker) proportional to the distribution of clients in each of those professions. Surveys were conducted with 208 females and 192 males at baseline. At endline, we were able to re-survey 183 of the females and 174 of the males surveyed at baseline (attrition rates of 12 percent and 9 percent, respectively). We replaced respondents who we were unable to re-survey with new respondents so that the endline sample sizes are the same as at baseline. We use these data to examine whether the criminalization of sex work had consequences for the general population.

Table VI presents the results of estimating equation 1 using the general population data, for males and females separately. We examine the impact of criminalizing sex work across three expenditure categories (grooming, entertainment, and medical) and the likelihood of reporting STI symptoms in the last three months. Expenditures on grooming are measured for the past month and include expenditures on hairstyle, personal hygiene, and make-up (for females). Entertainment expenditures, which could include money spent on commercial sex, are also measured for the past month. Medical expenditures include expenditures on drugs and clinic bills for the respondent in the past three months. All expenditures are measured in Indonesian rupiah, IDR.

Panel A shows that males living near the criminalized worksites spend less money on grooming and entertainment after criminalization occurs; these impacts are statistically significant at the 10 percent level. Criminalization causes a reduction of IDR 20,189 (about USD 1.50 in 2015) in expenditures on grooming. Likewise, entertainment expenditures decrease by IDR 42,479 (about USD 3 in 2015). We do not observe any statistically significant impacts on medical expenditures or reported STI symptoms for men. As expenditures on grooming and 
entertainment are likely to be higher among males who frequent commercial worksites, we interpret this as corroborative evidence that males in the surrounding areas are less likely to visit worksites after criminalization.

In contrast, Panel B of Table VI shows no statistically significant impacts of criminalization on expenditures across these categories by females living near the worksites. However, there is a statistically significant $(\mathrm{p}<0.05)$ increase in female reports of experiencing STI symptoms in the past 3 months. This is consistent with a scenario in which increased STI rates among sex workers at the criminalized worksites translate into higher STI rates among clients, who then pass these STIs on to their female sexual partners.

Overall, the general population analysis reflects the shrinking of the commercial sex market through the reduced grooming and entertainment expenditures by males living near the criminalized worksites. At the same time, the increased reported STI symptoms among the general population reflects the higher STI rates among sex workers that puts men (and therefore their partners) at greater risk of contracting an STI. The null result for self-reported STI symptoms for men may reflect the fact that STI symptoms can be less obvious for men.

\section{VII.C Consequences for Population STI Rates}

The increased rates of STIs among the sex worker population not only has negative impacts on sex worker health and the risk of contracting more serious diseases, such as HIV, but also has implications for population-wide STI rates. In this section, we compare transmission probabilities among the general population under criminalization, taking into account increased STI rates among sex workers, reduced condom use, and the change in the size of the market under several plausible counterfactual scenarios had criminalization not occurred. Appendix section 
III presents the equations and assumptions used in this exercise to calculate transmission probabilities, the underlying probabilities, and the estimated share of the population who are sex workers or clients (see Table III.I).

Using our baseline and endline data to measure STI rates and condom use, along with gonorrhea transmission probabilities (Centers for Disease Control and Prevention, 2013) and the probability that a condom prevents bacterial STI transmission (Gertler, Shah and Bertozzi, 2005), we calculate the change in probability that STI transmission occurs to three different groups of people who are connected to the sex market: clients of sex workers, the sexual partners of clients, and the sexual partners of sex workers. The increase in STI infections among sex workers, alongside the decrease in condom use at the criminalized worksites observed in Table II translates into significant increases in the probability that clients visiting the criminalized sites contract an STI as a result of a single instance of sexual intercourse from 4.4 percent to 7.1 percent (see Table III.II in the Appendix). Likewise, the probability that a client transmits an STI to a partner increases from 0.5 percent to 0.8 percent, and the probability that a a sex worker transmits an STI to a partner increases from 3 percent to 4.2 percent (also Table III.II). ${ }^{15}$

We then combine these transmission probabilities with estimates on the share of the population that falls into each group and the estimated change in the size of the sex market to estimate the impact of criminalization on STI rates among men and general population (non-sex worker) women. We present the resulting change in probability that males and females contract an STI as a result of a single instance of sexual intercourse in Table VII.

In Panel A of Table VII we show the impact of criminalization on STI rates in the short

\footnotetext{
${ }^{15}$ These probabilities take into account whether a client or a sex worker has a partner (conditional on condom use in commercial sex transactions). Therefore, these are not the probabilities that a partner of a client (sex worker) contracts the STI, rather the probability that a client (sex worker) has a partner and that partner contracts an STI.
} 
run, assuming that the market shrinks due to criminalization, as we saw in 2015 , and that the market would not have changed size between 2014 and 2015 had criminalization not occurred. These calculations suggest that, if the decrease in the size of the market was 60 percent, as observed in May-June 2015, then the probability a male contracts an STI would decrease by 37 percent. ${ }^{16}$ Similarly, the probability that a female (non-sex worker) would get an STI decreases by 41 percent. Under this scenario, general population STI health is improved in the presence of criminalization, and these benefits would only increase if we assume the sex market would have grown in the absence of criminalization.

When enumerators returned to the worksites five years later in October 2019, information from interviews with knowledgeable worksite informants about the number of sex workers at their sites and their knowledge of any new worksites revealed that the market had returned to the baseline size (see Figure III and Appendix Figure I.I). While sex worker numbers have rebounded to be almost exactly the same as prior to the closures, they are now distributed differently across formal and informal sites, with 29.4 percent of all workers being at informal sites (versus 10.3 percent prior to criminalization). This suggests that it is difficult to shut down the sex market in the long-run. ${ }^{17}$

Although the sex market has rebounded to its pre-criminalization size, it is unlikely that access to condoms and STI prevalence have returned to pre-criminalization rates. The reason for this is two-fold. First, formal worksites in Malang remain criminalized and enforcement

\footnotetext{
${ }^{16} \mathrm{~A}$ decrease of 60 percent is the largest decrease in market size that is consistent with our data. It is calculated by comparing the number of sex workers physically at our worksites during April 2014 (time of baseline surveys) to the number of sex workers physically at our worksites during May-June 2015 (time of endline surveys).

${ }^{17}$ As discussed earlier, we see little evidence of formal sector women moving to the informal sector. The segmentation of the sectors is, however, not so clean cut for clients. Some clients who find that they are unable to obtain sex in the formal sector (or who no longer find the formal sector attractive given the increased probability of police raids, etc.) will, over time, look for sex in the informal sector. This leads to new sex worker entrants in the informal sector to meet the increased demand.
} 
remains consistent with the status quo at endline in May-June 2015, with the consequence that government health clinics and non-government organizations are not able to provide services at the sites. There are local news reports of police raids of formal sites as recently as November 2019, with conditions at the worksite locations in worse condition than when we visited them in 2015 (Juandi, 2018; Vido, 2019). This is corroborated in the field notes from our survey firm during the revisit in October 2019. Second, a larger share of the market is now informal, where condom use tends to be lower and STI rates are higher than at formal worksites (Gertler and Shah, 2011; Jeal and Salisbury, 2007; Seib et al., 2009; Seib, Fischer and Najman, 2009). This suggests that, access to condoms may now be even lower and STI rates higher than we observed in May-June 2015 at endline.

To estimate the longer term change in the probability of STI transmission for men and nonsex worker women, we show results for four different counterfactual scenarios. First, Panel B(i) of Table VII shows that if the size of the market rebounds to the original 2014 size after criminalization, as the data suggest, and if the size of the market would have otherwise stayed the same size as February-March 2014 in the absence of criminalization, the probability of STI transmission is 59 percent higher for men and 48 percent higher for women.

In reality changes in the size of the sex market would have likely reflected changes in the supply and demand for sex in the absence of criminalization. The remaining three subpanels of Table VII present results for a range of different possible counterfactual scenarios in the absence of criminalization, all of which produce increases in the probability of STI transmission to the general population.

Panel B(ii) presents the counterfactual where the sex market growth rate in the absence 
of criminalization would have been equivalent to the rate of population growth of prime-aged men (18-65 years), who are the key drivers of the demand for commercial sex (Ahlburg and Jensen, 1998). The male population grew by 5.7 percent in East Java between 2010 and 2019. Assuming this resulted in a proportional increase in the demand for sex and was met by an increase in supply of sex workers, our calculations suggest that criminalization increased the probability of transmission in the general population by 51 percent (male) and 40 percent (nonsex worker female).

In Panel B(iii), we assume sex is a normal good (Ahlburg and Jensen, 1998), in which case we might expect the sex market to grow in proportion to GDP. Between 2014 and 2019 real GDP in the province of East Java grew by 31 percent, Statistics Indonesia (2019). If the sex market, in the absence of criminalization, would have grown at this rate, criminalization is associated with an increase in the probability of STI transmission among general population males of 22 percent and non-sex worker females of 14 percent. $^{18}$

Our final counterfactual, presented in Panel B(iv), draws on the elasticity of the size of the sex market with respect to unemployment estimated by Cook et al. (2014) for the US. They find that a 1 percentage point increase in the unemployment rate results in a decrease of about 4.5 percent in their measure of the size of the sex market. Applying the elasticity estimates from Cook et al. (2014) to the change in the unemployment rate in East Java over the period of -0.8 percentage points, generates a predicted increase of 3.6 percent in the size of the sex market in the absence of criminalization. In this case, criminalization is estimated to increase the probability of men contracting an STI by 54 percent and women by 43 percent.

\footnotetext{
${ }^{18}$ This is likely an overestimate of the increase in the size of the sex market as the positive impact of increased income on the demand side will be offset to some extent by the decrease in supply of sex work that is a consequence of greater job opportunities for women and their partners (Ahlburg and Jensen, 1998).
} 
In summary, the evidence points to overall negative health effects on the general population due to criminalization in the long-term, due to the rebound in the size of the market and the continued marginalization of the formal worksites in Malang that prevent the institution of safety measures, such as condom distribution. Further, the estimates above are all first-round effects, with STI prevalence likely to increase even more over time as these people pass on the infection to other partners.

\section{Discussion and Conclusion}

This paper presents new causal evidence on the impact of criminalizing sex work in a lowincome setting. We examine the health impacts on sex workers; the economic consequences for sex workers and their children; and the consequences for population health. Criminalizing sex work significantly increases the rate of sexually transmitted infections among female sex workers. The increase in STIs is driven by large decreases in the availability of condoms and their use. Women who left sex work as a result of criminalization also suffer in terms of their ability to earn enough to meet their daily needs and their general well-being, and there is evidence of negative impacts on their children.

In addition to having measurable negative consequences for female sex workers and their families, the increased prevalence of STIs among sex workers, and decreased use of condoms, has implications for overall public health. Our estimates indicate that criminalization of sex work in the long-run is likely to increase STI infections, including HIV, in the general population.

Aggregating across these impacts to assess the overall welfare impact is an exercise that is 
inherently dependent on the weights one attaches to the differing components and is beyond the scope of this paper. What is clear, is that criminalization resulted in reduced condom availability and use, increased STI rates among sex workers, increased STI prevalence among clients and, likely, increased prevalence among general population men and women. To the extent that the size of the sex market may be smaller now than it would have been in the absence of criminalization may be assessed by some to have a positive welfare impact. However, from a health perspective, criminalization of sex work is likely to be counterproductive. A common response to these findings is to argue for criminalization alongside the provision of condoms and health services. Such arguments ignore the fact that it is criminalization that restricts the ability of organizations to support sex worker health and inhibits sex workers' ability to openly access support and services.

University of Melbourne George Washington University University of California, Los Angeles \& NBER 


\section{References}

Ahlburg, Dennis and Eric Jensen. 1998. The Economics of the Commercial Sex Industry and its Implications for HIV/AIDS Prevention Policies. Brussels: European Commission chapter 9, pp. 147-73.

Amnesty International. 2015. "Global Movement Votes to Adopt Policy to Protect Human Rights of Sex Workers." Press Release. http://www.amnestyusa.org/news/press-releases/ global-movement-votes-to-adopt-policy-to-protect-human-rights-of-sex-workers.

Bisschop, Paul, Stephen Kastoryano and Bas van der Klaauw. 2017. "Street Prostitution Zones and Crime." American Economic Journal: Economic Policy 9(4):28-63.

Bupati Merasa Ditelikung Pengelola Eks Lokalisasi. 2014. URL: http://radarmalang.co.id/bupati-merasa-ditelikung-pengelola-eks-lokalisasi-12108.htm

Cameron, A. Colin, Jonah B. Gelbach and Douglas L. Miller. 2008. "Bootstrap-Based Improvements for Inference with Clustered Errors." The Review of Economics and Statistics 90(3):414-427.

Centers for Disease Control and Prevention. 2013. STD Curriculum for Clinical Educators. Technical report Washington, DC: Department of Health and Human Services.

Ciacci, Riccardo. 2019. "Banning the Purchase of Prostitution Increases Rape: Evidence from Sweden.” Working Paper.

Cook, Cody, Scott Loring, Teddy Niemiec and Kayla Reinherz. 2014. "Macroeconomic Forces within the Market for Prostitution." Comparative Advantage Spring:84-94.

Cunningham, Scott and Manisha Shah. 2018. "Decriminalizing Indoor Prostitution: Implications for Sexual Violence and Public Health.” The Review of Economic Studies 85(3):1683-1715.

Dodillet, Susanne and Petra Ostergren. 2011. "The Swedish Sex Purchase Act: Claimed Success and Documented Effects." Conference paper presented at the International Workshop: Decriminalizing Prostitution and Beyond: Practical Experiences and Challenges. The Hague pp. 1-36.

Farmer, Amy and Andrew W. Horowitz. 2013. "Prostitutes, Pimps, and Brothels: Intermediaries, Information, and Market Structure in Prostitution Markets." Southern Economic Journal 79(3):513-528.

Gertler, Paul and Manisha Shah. 2011. "Sex Work and Infection: What's Law Enforcement Got to Do With It?" Journal of Law and Economics 54.

Gertler, Paul, Manisha Shah and Stefano Bertozzi. 2005. "Risky Business: The Market for Unprotected Commercial Sex." Journal of Political Economy 113(3).

Ghosal, Sayantan, Smarajit Jana, Anandi Mani, Sandip Mitra and Sanchari Roy. 2016. "Mujer Mas Segura(Safer Women): a combination prevention intervention to reduce sexual and injection risks among female sex workers who inject drugs." University of Warwick Department of Economics Working Paper Series (302):1-48.

Indonesia National AIDS Commission. 2014. Global AIDS Response Progress Reporting: Indonesia Country Progress Report 2014. Technical report Indonesia National AIDS Commission.

Ito, Seiro, Aurélia Lépine and Carole Treibich. 2018. "The Effect of Sex Work Regulation on Health and Wellbeing of Sex Workers: Evidence from Senegal." Health Economics .

Jeal, Nikki and Chris Salisbury. 2007. "Health needs and service use of parlour-based prostitutes compared with street-based prostitutes: a cross-sectional survey." An International Journal of Obstetrics and Gynaecology 114(7):875-881. 
Juandi, Andi. 2018. "Polisi razia sejumlah lokalisasi di Kabupaten Malang." Elshinta .

URL: https://elshinta.com/news/145000/2018/05/12/polisi-razia-sejumlah-lokalisasi-di-kabupaten-malang

Kendall, Megan and Karina Razli. 2010. Sex Work and HIV: Indonesia. Technical report Evidence to Action HIV and AIDS Data Hub for Asia-Pacific.

Kharsany, Ayesha B M and Quarraisha A Karim. 2016. "HIV Infection and AIDS in Sub-Saharan Africa: Current Status, Challenges and Opportunities." The Open AIDS journal 10:34-48.

Kling, Jeffrey R, Jeffrey B Liebman and Lawrence F Katz. 2007. "Experimental analysis of neighborhood effects." Econometrica 75(1):83-119.

Lancet. 2015. “Keeping sex workers safe.” The Lancet 386(9993):504.

Lee, Samuel and Petra Persson. 2015. "Human Trafficking and Regulating Prostitution.” Working Paper.

Levy, Jay and Pye Jakobsson. 2014. "Sweden's abolitionist discourse and law: Effects on the dynamics of Swedish sex work and on the lives of Sweden's sex workers." Criminology \& Criminal Justice 14(5):593-607.

Lyons, Carrie E., Sosthenes Ketende, Daouda Diouf, Fatou M. Drame, Benjamin Liestman, Karleen Coly, Cheikh Ndour, Gnilane Turpin, Souleymane Mboup, Karim Diop, Coumba Toure-Kane, Delivette Castor, Nafissatou Leye-Diouf and Stefan Baral. 2017. "Potential Impact of Integrated Stigma Mitigation Interventions in Improving HIV/AIDS Service Delivery and Uptake for Key Populations in Senegal." Journal of Acquired Immune Deficiency Syndrome 74(S1):S52-S59.

Magnani, Robert, Pandu Riono, Nurhayati, Eko Saputro, Dyah Mustikawati, Atiek Anartati, Ciptasari Prabawanti, Nurholis Majid and Guy Morineau. 2010. "Sexual Risk Behaviors, HIV and other sexully transmitted infections among female sex workers in Indonesia." Sexually Transmitted Infections 86:393-399.

Malang Post. 2014. "November, Pemkab tutup Tujuh Lokalisasi." Malang Post . URL: http://www.malang-post.com/metro-raya/89162-november-pemkab-tutup-tujuh-lokalisasi

Manian, Shanthi. 2018. "Health Certification in the Market for Sex Work: A Field Experiment in Dakar, Senegal." Working Paper.

National AIDS Control Organisation. 2018. 2018 estimates from the Joint United Nations Programme on HIV/AIDS. Technical report National AIDS Control Organisation.

Nguyen, Amanda. 2016. "Optimal Regulation of Illegal Goods: The Case of Massage Licensing and Prostitution." UCLA Working Paper.

Patterson, Thomas L., Brent Mausbach, Remedios Lozada, Hugo Staines-Orozco, Shirley J. Semple, Miguel FragaVallejo, Prisci Orozovich, Daniela Abramovitz, Adela de la Torre, Hortensia Amaro, Gustavo Martinez, Carlos Magis-Rodriguez and Steffanie A. Strathdee. 2008. "Efficacy of a Brief Behavioral Intervention to Promote Condom Use Among Female Sex Workers in Tijuana and Ciudad Juarez, Mexico." American Journal of Public Health 98(11):2051-2057.

Pitpitan, Eileen V, Claudia V Chavarin, Shirley J Semple, Carlos Magis-Rodriguez, Steffanie A Strathdee and Thomas L Patterson. 2014. "Hombre Seguro (Safe Men): a sexual risk reduction intervention for male clients of female sex workers." BMC Public Health 14(475):1-48.

Pruss-Ustun, Annette, Jennyfer Wolf, Tim Driscoll, Louisa Degenhardt, Maria Neira and Jesus Maria Garcia Calleja. 2013. "HIV Due to Female Sex Work: Regional and Global Estimates." PLOSONE 8(5):1-7.

RCA. 2016. Reality Check Approach Short Insights Study: Perspectives of Sex Workers and their Clients on the Closures of their Places of Work. Technical report Reality Check Approach. 
Seib, Charlotte, Jane Fischer and Jackob Najman. 2009. "The health of female sex workers from three industry sectors in Queensland, Australia." Social Science and Medicine 68(3):473-478.

Seib, Charlotte, Joseph Debattista, Jane Fischer, Michael Dunne and Jackob Najman. 2009. "Sexually transmitted infections among sex workers and their clients: variation in prevalence between sectors of the industry." Sexual Health 6(1):45-50.

Statistics Indonesia. 2019. Statistik Indonesia - Statistical Yearbook of Indonesia 2019. Technical report.

Sukarelawati, Endang. 2014. "Tujuh lokalisasi Kabupaten Malang ditutup usai Lebaran.” Antara News . URL: http://www.antaranews.com/berita/443721/tujuh-lokalisasi-kabupaten-malang-ditutup-usai-lebaran

Thai National AIDS Commission. 2014. Thailand Ending AIDS: 2014 Thailand AIDS Response Progress Report. Technical report Thai National AIDS Commission.

Tribunews.com. 2014. "Tujuh Lokalisasi di Kabupaten Malang Ditutup November.” Tribunews.com . URL: $\quad$ http://www.tribunnews.com/regional/2014/07/11/tujuh-lokalisasi-di-kabupaten-malang-ditutupnovember

UNAIDS and World Bank. 2010. New HIV Infections by mode of transmission in West Africa: A Multi-Country Analysis. Technical report.

Vandepitte, Judith, Rob Lyerla, Gina Dallabetta, Francois Crabbé, Michel Alary and Anne Buvé. 2006. "Estimates of the number of female sex workers in different regions of the world." Sexually Transmitted Infections 82(3):iii18-iii25.

Vera, Alicia, Daniela Abramovitz, Remedios Lozada, Gustavo Martinez, M Gudelia Rangel, Hugo Staines, Thomas L Patterson and Steffanie A Strathdee. 2012. "Mujer Mas Segura (Safer Women): a combination prevention intervention to reduce sexual and injection risks among female sex workers who inject drugs." $B M C$ Public Health 12(1).

Vido, Elfran. 2019. "Suko Masih "Beroperasi”, Bupati pun Bereaksi.” Radar Malang . URL: https://radarmalang.id/suko-masih-beroperasi-bupati-pun-bereaksi/ 


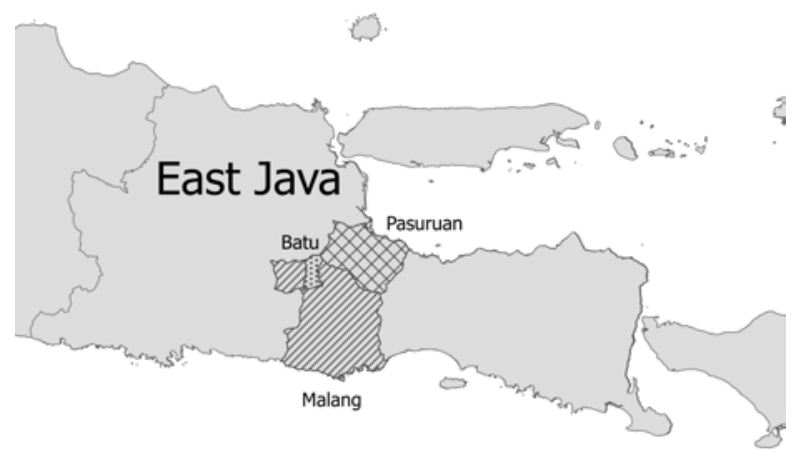

Figure I Study Area

Notes: The area marked by diagonal lines, Malang, is the area where formal sex work was criminalized. 


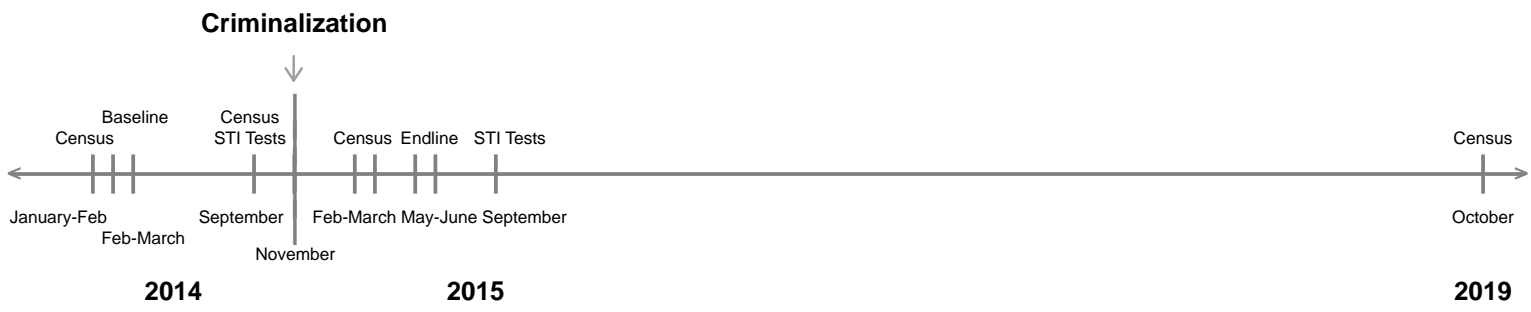

Figure II Study Timeline

Notes. This figure shows the timeline of the main data collection and study activities spanning from January 2014 to September 2015 , as well as the additional data collection activity that took place in October 2019. Censuses of worksites were taken at four points in time: January-February 2014, September 2014, February-March 2015, and October 2019. Surveys were conducted with sex workers and clients from February-March 2014 and May-June 2015. Biological STI tests were conducted in September 2014 and 2015 . The criminalization of worksites took place in November 2014, between the two waves of survey data collection. 


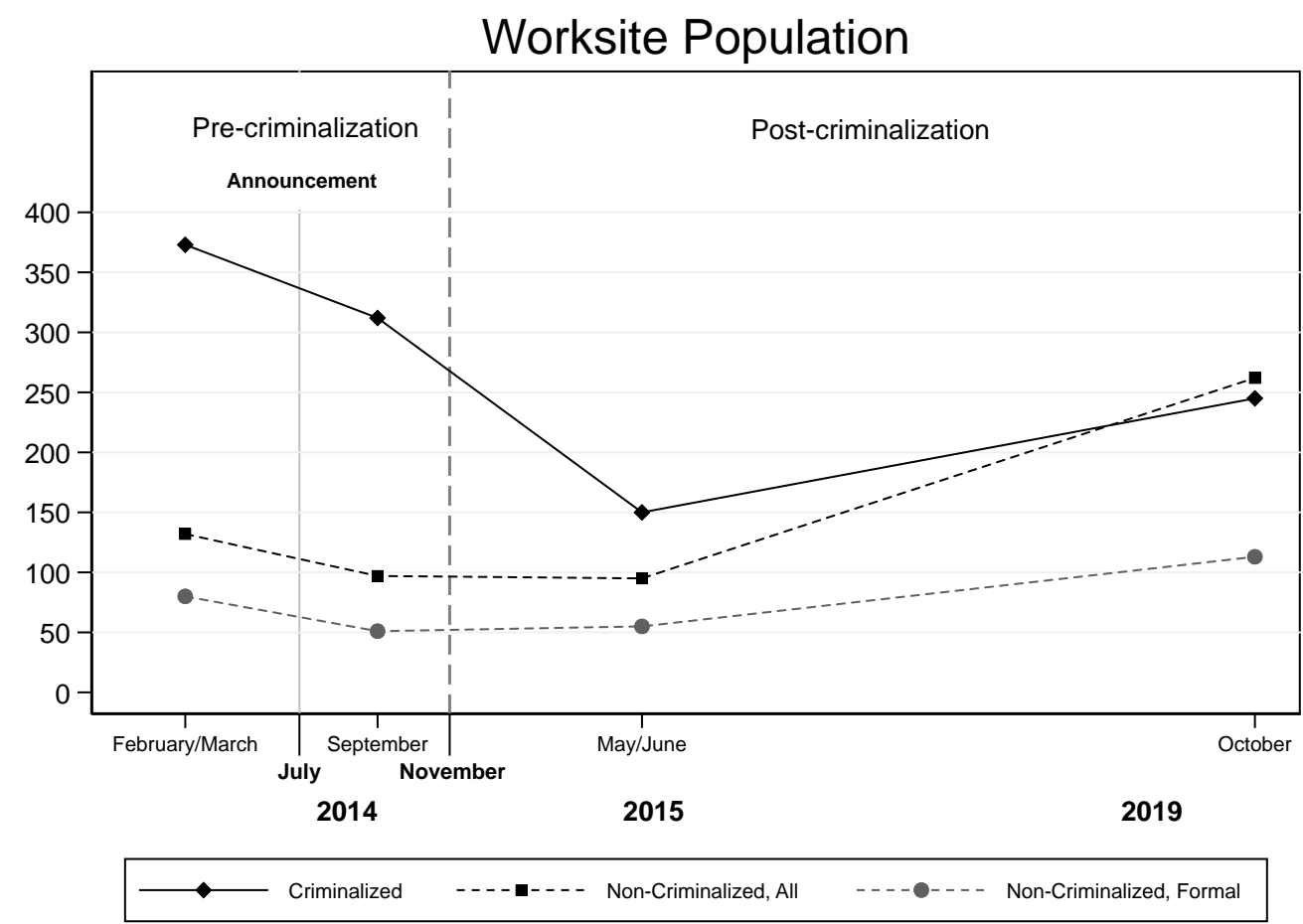

Figure III Impact of Criminalization on Sex Worker Population

Notes. This figure presents the change in the population at the study worksites over time. The sex worker population is measured in Feburary-March 2014, September 2014 and May-June 2015. The first point, February-March 2014, represents the populations at worksites during the baseline survey. There were 373 sex workers at the criminalized worksites, 132 sex workers at all non-criminalized worksites, and 80 sex workers at the formal non-criminalized worksites. The second point is based on the population of women found at the worksites during a census of the worksites taken in September 2014, after the worksite closures were announced but before the worksites were closed. The figures for May-June 2015 show the population of sex workers at the worksites during the endline survey. The announcement of the worksite closures occurred in July 2014 and is indicated by a light grey dashed vertical line. The worksite closures occurred in November 2014, indicated by a solid, dark vertical line. The final point, in October 2019, is from a survey of knowledgeable worksite representatives five years after the criminalization. 

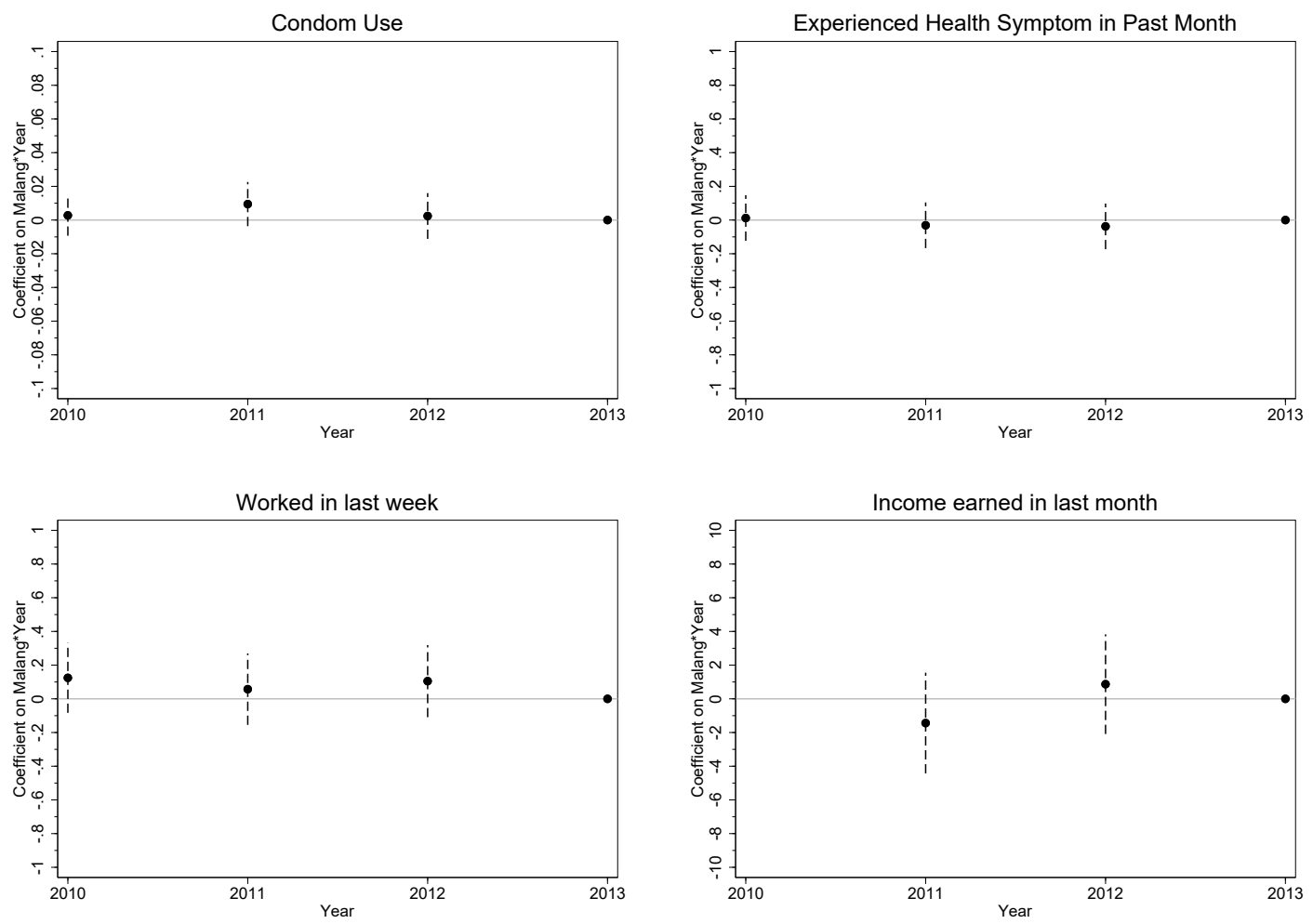

Figure IV Comparisons of trends in outcomes in Malang with Pasuruan and Batu prior to Criminalization, SUSENAS 2010-2013, Females aged 28-42

Notes. The figure plots coefficients on the Malang-specific year effects controlling for region and year fixed effects for each outcome (condom use reported by married women (0/1); experienced health symptoms in last month (0/1), worked in last week (0/1), and earnings last month from main job, reported by all women). The vertical dashed lines are the 95 percent confidence intervals on the coefficient. The 2010 Susenas did not include a question on income earned in the last month. 


\section{Test Positive, All Worksites}

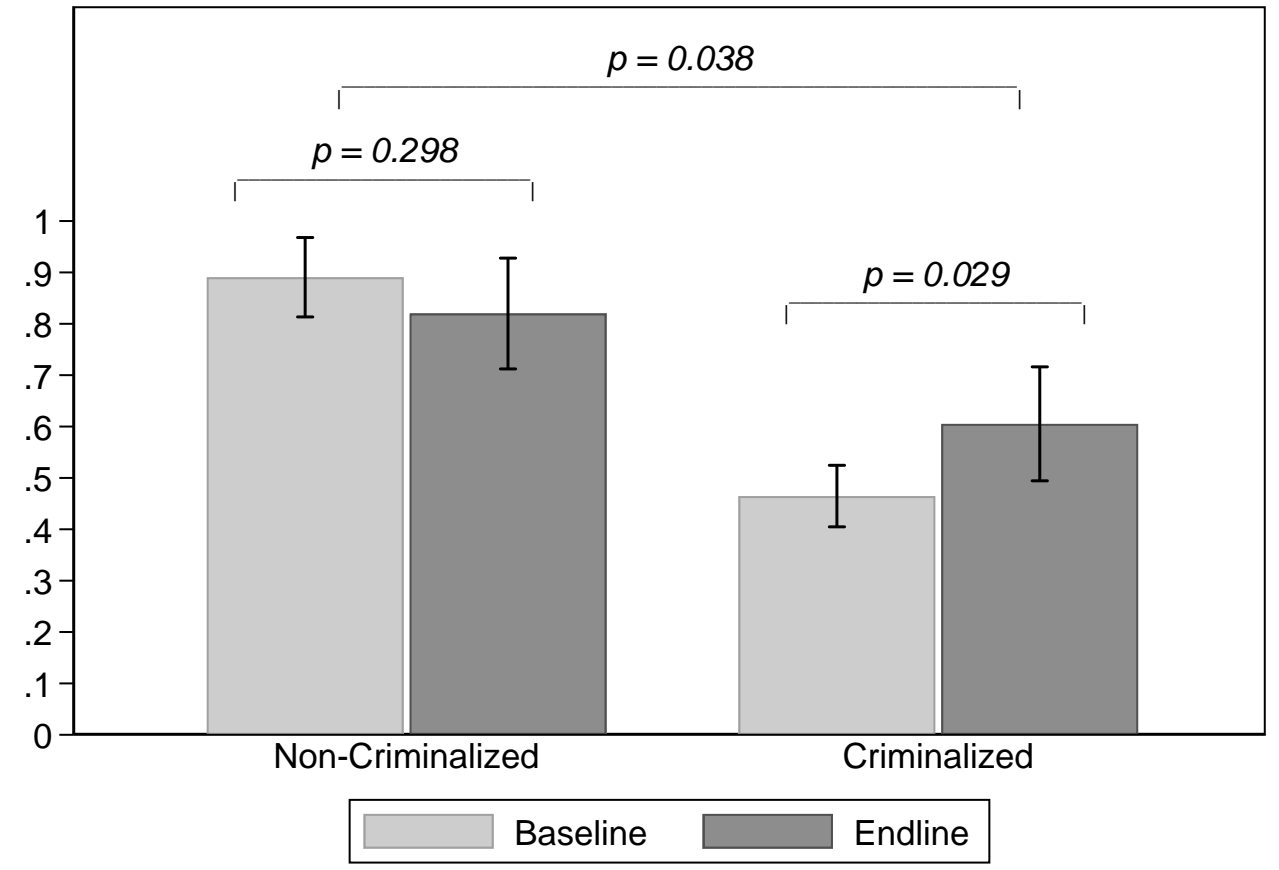

Figure V STI prevalence by Criminalization Status

Notes. This figure presents the STI rates of sex workers at baseline and endline according to their criminalization status, using the biological testing data. The two p-values over each set of two bars is the p-value for the test in differences of the means at baseline and endline in non-criminalized and criminalized worksites, respectively. The p-value of 0.038 spanning all four bars is the p-value on the DD estimate of the impact of criminalization on STI rates. 


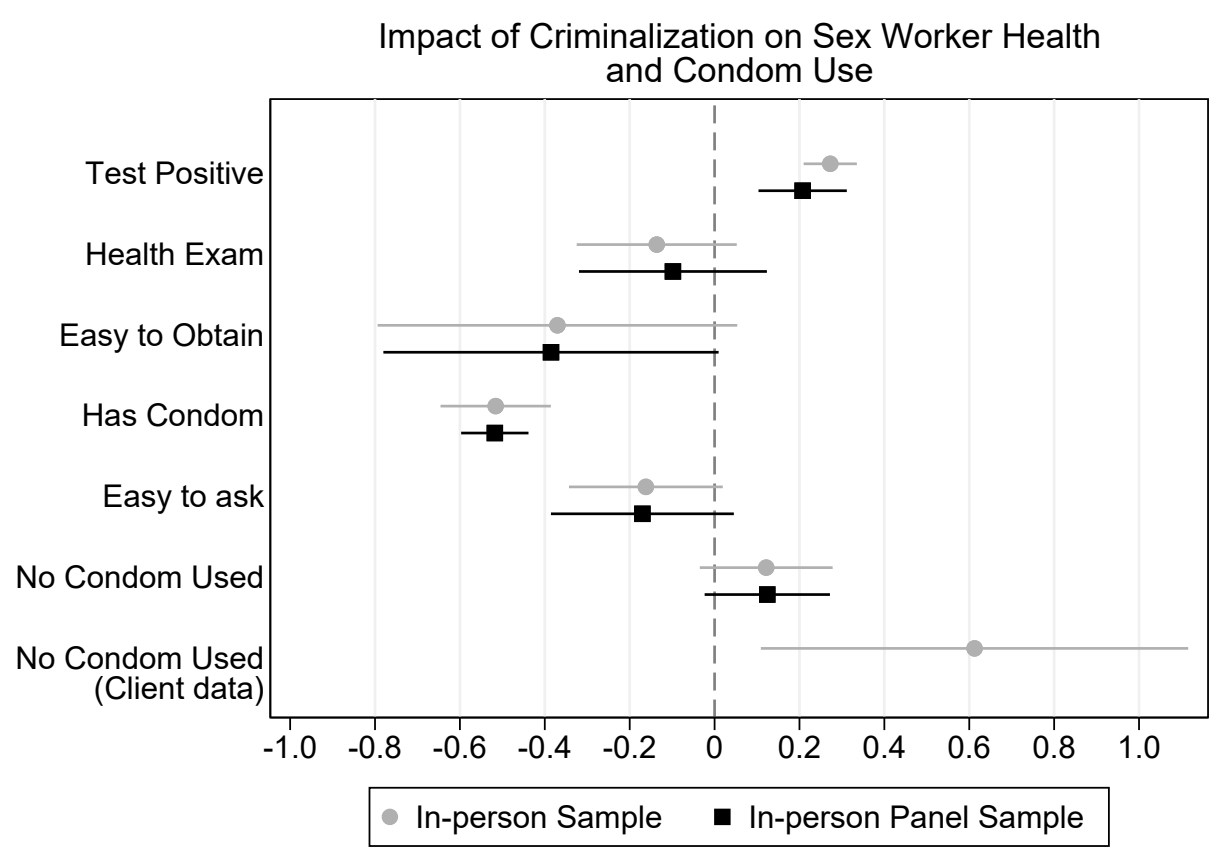

Figure VI Estimates of Criminalization Impacts

Notes. The figure plots the coefficient point estimates of $\beta_{1}$ from equation (1) and their respective 95 percent confidence intervals for each dependent variable in Table 2 . 

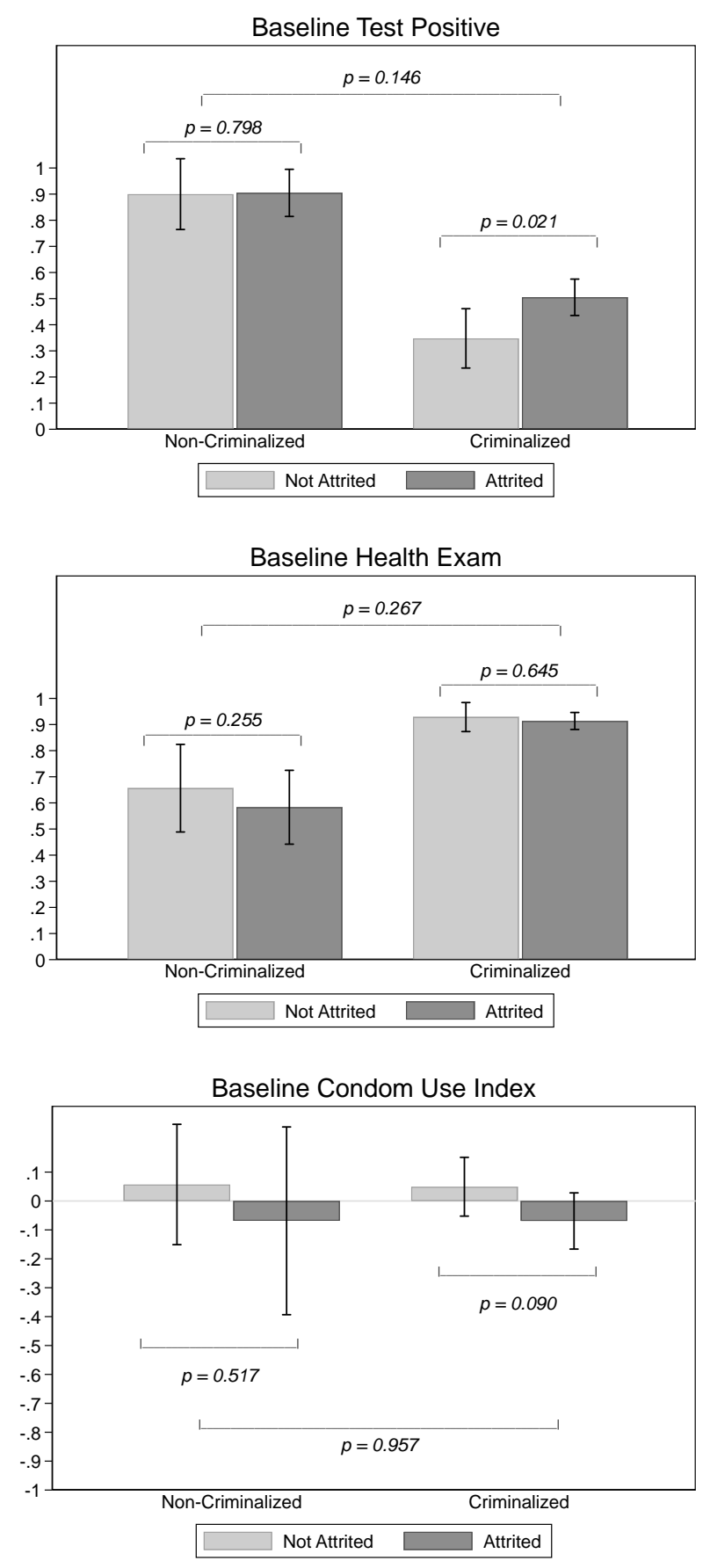

Figure VII Baseline STI prevalence, Health Exams and Condom Use Index by Criminalization and Attrition Status

Notes. This figure presents STI prevalence, health exam rates, and the mean value of the condom use index at baseline according to attrition and criminalization status. The p-values spanning each set of two bars are the p-values for tests of differences of means across attritors and non-attritors, and the p-value spanning all four bars is the p-value for the test that sex workers attrited differentially from non-criminalized and criminalized worksites. 
Table I Summary Statistics: Sex Workers and Clients

\begin{tabular}{|c|c|c|c|}
\hline & (1) & (2) & (3) \\
\hline & Crim & Non-Crim & $\begin{array}{c}\text { Diff } \\
(P \text {-Value })\end{array}$ \\
\hline \multicolumn{4}{|c|}{ A. Female Sex Worker Characteristics } \\
\hline Married & $\begin{array}{c}0.180 \\
(0.028)\end{array}$ & $\begin{array}{l}0.197 \\
(0.059)\end{array}$ & 0787 \\
\hline Divorced or Widowed & 0.777 & 0.727 & 0419 \\
\hline Never Married & $\begin{array}{c}0.043 \\
(0.007)\end{array}$ & $\begin{array}{c}0.076 \\
(0.022)\end{array}$ & 0.162 \\
\hline Years of Education & $\begin{array}{c}5.820 \\
(0.180)\end{array}$ & $\begin{array}{c}5.727 \\
(0.407)\end{array}$ & 0.210 \\
\hline Age & $\begin{array}{l}34.539 \\
(0.959)\end{array}$ & $\begin{array}{l}35.803 \\
(1.844)\end{array}$ & 0.542 \\
\hline Children & $\begin{array}{c}0.906 \\
(0.018)\end{array}$ & $\begin{array}{c}0.864 \\
(0.033)\end{array}$ & 0.264 \\
\hline Years at Location & $\begin{array}{c}2.091 \\
(0.209)\end{array}$ & $\begin{array}{c}3.197 \\
(0.813)\end{array}$ & 0.198 \\
\hline Discount Factor & $\begin{array}{c}0.388 \\
(0.029)\end{array}$ & $\begin{array}{c}0.374 \\
(0.033)\end{array}$ & 0.740 \\
\hline Risk Tolerance & $\begin{array}{c}0.380 \\
(0.029)\end{array}$ & $\begin{array}{c}0.323 \\
(0.066)\end{array}$ & 0.431 \\
\hline \multicolumn{4}{|c|}{ B. Female Sex Workers Outcomes } \\
\hline Biological Tests & $\begin{array}{c}0.465 \\
(0.097)\end{array}$ & $\begin{array}{c}0.891 \\
(0.028)\end{array}$ & $0.002 * * *$ \\
\hline Health Exam & $\begin{array}{c}0.917 \\
(0.015)\end{array}$ & $\begin{array}{c}0.614 \\
(0.0714)\end{array}$ & $0.001 * * *$ \\
\hline Easy to Obtain & $\begin{array}{c}0.713 \\
(0.155)\end{array}$ & $\begin{array}{c}0.666 \\
(0.096)\end{array}$ & 0.793 \\
\hline Has Condom & $\begin{array}{c}0.893 \\
(0.033)\end{array}$ & $\begin{array}{c}0.401 \\
(0.064)\end{array}$ & $<0.001 * * *$ \\
\hline Easy to Ask & $\begin{array}{c}0.550 \\
(0.062)\end{array}$ & $\begin{array}{c}0.462 \\
(0.050)\end{array}$ & 0.269 \\
\hline Condom Price & $\begin{array}{l}929 \\
(88)\end{array}$ & $\begin{array}{c}731 \\
(128)\end{array}$ & 0.210 \\
\hline No Condom Used & $\begin{array}{c}0.144 \\
(0.030)\end{array}$ & $\begin{array}{c}0.281 \\
(0.060)\end{array}$ & $0.055^{*}$ \\
\hline Sample Size & 373 & 132 & \\
\hline \multicolumn{4}{|c|}{ C. Client Characteristics } \\
\hline Married & $\begin{array}{c}0.641 \\
(0.039)\end{array}$ & $\begin{array}{c}0.525 \\
(0.052)\end{array}$ & $0.087 *$ \\
\hline Divorced or Widowed & $\begin{array}{c}0.155 \\
(0.026)\end{array}$ & $\begin{array}{c}0.175 \\
(0.043)\end{array}$ & 0.679 \\
\hline Never Married & $\begin{array}{c}0.205 \\
(0.051)\end{array}$ & $\begin{array}{c}0.300 \\
(0.071)\end{array}$ & 0.280 \\
\hline Years of Education & $\begin{array}{c}8.777 \\
(0.544)\end{array}$ & $\begin{array}{c}7.900 \\
(0.462)\end{array}$ & 0.219 \\
\hline Age & $\begin{array}{l}39.250 \\
(1.414)\end{array}$ & $\begin{array}{l}36.538 \\
(2.583)\end{array}$ & 0.359 \\
\hline Discount Factor & $\begin{array}{c}0.225 \\
(0.030)\end{array}$ & $\begin{array}{c}0.340 \\
(0.067)\end{array}$ & 0.126 \\
\hline Risk Tolerance & $\begin{array}{c}0.523 \\
(0.051)\end{array}$ & $\begin{array}{c}0.500 \\
(0.053)\end{array}$ & 0.753 \\
\hline No Condom Used & $\begin{array}{c}0.345 \\
(0.042)\end{array}$ & $\begin{array}{c}0.498 \\
(0.080)\end{array}$ & $0.097 *$ \\
\hline
\end{tabular}

Sample size $\quad 220 \quad 80$

\footnotetext{
Notes. This table reports summary statistics from baseline data. Standard errors are clustered at the worksite level. The p-value is from a test of difference of mean between respondents at criminalized and non-criminalized worksites. "Married", "Divorced or Widowed", and "Never Married" are indicator variables equal to 1 if the variable corresponds to the respondent's marital status and 0 otherwise. "Years of education" measures the reported number of years of school, "age" is the respondent's age in years, "children" is an if one child "years at location" is the reported number of years that the sex worker has che "years a "ch the has been at the curen workste locaten, "discount facto" "is the calculated discount factor for the respondent and "risk tolerance" is an indicator equal to 1 if the respondent chose one of the two riskiest options during a risk game, both discussed in the Appendix section II.
} 
Table II Impact of Criminalization on Sex Worker Health and Condom Use

\begin{tabular}{|c|c|c|c|c|c|c|c|c|c|}
\hline & (1) & (2) & (3) & (4) & (5) & (6) & (7) & (8) & (9) \\
\hline & $\begin{array}{c}\text { Test } \\
\text { Positive }\end{array}$ & $\begin{array}{l}\text { Health } \\
\text { Exam }\end{array}$ & $\begin{array}{l}\text { Condom } \\
\text { Use Index }\end{array}$ & $\begin{array}{l}\text { Easy to } \\
\text { Obtain }\end{array}$ & $\begin{array}{c}\text { Has } \\
\text { Condom }\end{array}$ & $\begin{array}{l}\text { Condom } \\
\text { Price }\end{array}$ & $\begin{array}{l}\text { Easy to } \\
\text { Ask }\end{array}$ & $\begin{array}{l}\text { No Condom } \\
\text { Used }\end{array}$ & $\begin{array}{c}\text { Client Data } \\
\begin{array}{c}\text { No Condom } \\
\text { Used }\end{array}\end{array}$ \\
\hline \multicolumn{9}{|c|}{ A. Sex Workers in Sex Work, In-person Sample, with controls } & \\
\hline Crim $\times$ Post & $\begin{array}{c}0.273^{* * * *} \\
(0.032) \\
{[0.010]}\end{array}$ & $\begin{array}{l}-0.136 \\
(0.096) \\
{[0.190]}\end{array}$ & $\begin{array}{c}-0.871^{* * * *} \\
(0.178) \\
{[0.014]}\end{array}$ & $\begin{array}{l}-0.370 \\
(0.216) \\
{[0.318]}\end{array}$ & $\begin{array}{c}-0.516^{* * * *} \\
(0.066) \\
{[0.002]}\end{array}$ & $\begin{array}{l}1.47 * * * \\
(0.463) \\
{[0.002]}\end{array}$ & $\begin{array}{l}-0.162 \\
(0.092) \\
{[0.144]}\end{array}$ & $\begin{array}{c}0.122 \\
(0.114) \\
{[0.358]}\end{array}$ & $\begin{array}{c}0.613 * * \\
(0.349) \\
{[0.048]}\end{array}$ \\
\hline $\begin{array}{l}\text { Observations } \\
\text { Baseline Mean }\end{array}$ & $\begin{array}{c}459 \\
0.465\end{array}$ & $\begin{array}{c}703 \\
0.916\end{array}$ & $\begin{array}{l}703 \\
0.00\end{array}$ & $\begin{array}{c}703 \\
0.714\end{array}$ & $\begin{array}{c}703 \\
0.893\end{array}$ & $\begin{array}{c}703 \\
930 \mathrm{IDR}\end{array}$ & $\begin{array}{c}703 \\
0.550\end{array}$ & $\begin{array}{l}1956 \\
0.144\end{array}$ & $\begin{array}{l}1253 \\
0.386\end{array}$ \\
\hline $\begin{array}{l}\text { Worksite Fixed Effects } \\
\text { Individual Fixed Effects }\end{array}$ & $\begin{array}{l}\mathrm{Y} \\
\mathrm{N}\end{array}$ & $\begin{array}{l}\mathrm{Y} \\
\mathrm{N}\end{array}$ & $\begin{array}{l}\mathrm{Y} \\
\mathrm{N}\end{array}$ & $\begin{array}{l}\mathrm{Y} \\
\mathrm{N}\end{array}$ & Y & Y & Y & $\begin{array}{l}\mathrm{N} \\
\mathrm{Y}\end{array}$ & $\begin{array}{l}\mathrm{N} \\
\mathrm{Y}\end{array}$ \\
\hline $\begin{array}{l}\text { Observations } \\
\text { Baseline Means }\end{array}$ & $\begin{array}{c}148 \\
0.340\end{array}$ & $\begin{array}{c}288 \\
0.935\end{array}$ & $\begin{array}{l}288 \\
0.00\end{array}$ & $\begin{array}{c}288 \\
0.774\end{array}$ & $\begin{array}{c}288 \\
0.881\end{array}$ & $\begin{array}{c}288 \\
885 \text { IDR }\end{array}$ & $\begin{array}{l}288 \\
548\end{array}$ & $\begin{array}{c}786 \\
0.169\end{array}$ & \\
\hline $\begin{array}{l}\text { Worksite Fixed Effects } \\
\text { Individual Fixed Effects }\end{array}$ & $\begin{array}{l}\mathrm{Y} \\
\mathrm{N}\end{array}$ & $\begin{array}{l}\mathrm{Y} \\
\mathrm{N}\end{array}$ & $\begin{array}{l}\mathrm{Y} \\
\mathrm{N}\end{array}$ & $\begin{array}{l}\mathrm{Y} \\
\mathrm{N}\end{array}$ & $\begin{array}{l}\mathrm{Y} \\
\mathrm{N}\end{array}$ & $\begin{array}{l}\mathrm{Y} \\
\mathrm{N}\end{array}$ & $\begin{array}{l}\mathrm{Y} \\
\mathrm{N}\end{array}$ & $\begin{array}{l}\mathrm{N} \\
\mathrm{Y}\end{array}$ & $\begin{array}{l}\mathrm{N} \\
\mathrm{Y}\end{array}$ \\
\hline Unit of Observation & Individual & Individual & Individual & Individual & Individual & Individual & Individual & Transaction & Transaction \\
\hline \multicolumn{10}{|c|}{$\begin{array}{l}\text { Notes. This table reports estimates of } \beta_{1} \text { from equation (1). "Test Positive" is an indicator for a positive result for the biological test. "Health Exam" is an indicator } \\
\text { variable equal to } 1 \text { if the sex worker reported having a medical exam with a speculum in the past } 3 \text { months. "Condom Use Index" is generated from standardizing each } \\
\text { of the measures in columns } 4-7 \text { around the means and standard deviations of their values in criminalized worksites at baseline and taking the unweighted average across } \\
\text { variables. "Easy to obtain" is an indicator equal to } 1 \text { if the sex worker reports that it is easy to obtain a condom within the worksite. "Has Condom" is an indicator for the } \\
\text { sex worker having a condom on her that she can produce at the time of the interview. "Condom Price" is the hyperbolic inverse sine transformation of the reported price } \\
\text { of condoms. "No Condom Used" is an indicator variable equal to } 1 \text { if the sex worker (or client) reports that she(he) did not use a condom at all during a transaction. The } \\
\text { regression in column } 1 \text { includes worksite fixed effects. Regressions in columns } 2-7 \text { include controls for marital status, years of education, age, has children, number of } \\
\text { years at the worksite, discount factor, risk tolerance, and worksite fixed effects. In column } 8 \text {, controls include indicators for whether the client is a regular, an outsider, } \\
\text { cleaner than the average client, handsome, old, and rich in addition to the sex worker fixed effects. In column } 9 \text {, controls include indicators for whether the client sees } \\
\text { the sex worker regularly and whether the client finds the sex worker more attractive than average or cleaner than average, in addition to client fixed effects. Standard } \\
\text { errors are presented in parentheses and are clustered at the worksite level. We also present Wild cluster-bootstrap percentile-t p-values in brackets below the conventional } \\
\text { standard error following Cameron, Gelbach, and Miller (2008). Stars correspond to the p-value. * p }<0.10, * * p<0.05, * * * p<0.01 \text {. }\end{array}$} \\
\hline
\end{tabular}




\section{Table III Impact of Criminalization on Worksite Operations}

\begin{tabular}{|c|c|c|c|c|c|c|}
\hline & (1) & (2) & (3) & (4) & (5) & (6) \\
\hline & $\begin{array}{l}\text { Worksite } \\
\text { Index }\end{array}$ & $\begin{array}{l}\text { No. of } \\
\text { Clients }\end{array}$ & $\begin{array}{l}\text { No. of } \\
\text { Trans. }\end{array}$ & $\begin{array}{c}\text { No. of } \\
\text { Hrs Worked }\end{array}$ & Price & $\begin{array}{c}\text { Wkly } \\
\text { Earnings }\end{array}$ \\
\hline \multicolumn{7}{|c|}{ A. Sex Workers in Sex Work, In-person Sample } \\
\hline Crim $\times$ Post & $\begin{array}{c}0.149 \\
(0.185) \\
{[0.548]}\end{array}$ & $\begin{array}{c}2.50 \\
(2.27) \\
{[0.392]}\end{array}$ & $\begin{array}{c}2.25 \\
(2.24) \\
{[0.406]}\end{array}$ & $\begin{array}{c}-5.56 \\
(7.38) \\
{[0.480]}\end{array}$ & $\begin{array}{l}-0.051 \\
(0.111) \\
{[0.630]}\end{array}$ & $\begin{array}{c}0.512 \\
(0.617) \\
{[0.508]}\end{array}$ \\
\hline $\begin{array}{l}\text { Observations } \\
\text { Baseline Mean }\end{array}$ & $\begin{array}{l}703 \\
0.00\end{array}$ & $\begin{array}{l}703 \\
8.40\end{array}$ & $\begin{array}{l}703 \\
8.45\end{array}$ & $\begin{array}{r}703 \\
57.2\end{array}$ & $\begin{array}{c}1,956 \\
106,054 \mathrm{IDR}\end{array}$ & $\begin{array}{c}703 \\
735,040 \mathrm{IDR}\end{array}$ \\
\hline \multicolumn{7}{|c|}{ B. Sex Workers in Sex Work, In-person Panel Sample } \\
\hline Crim $\times$ Post & $\begin{array}{l}-0.031 \\
(0.128) \\
{[0.830]}\end{array}$ & $\begin{array}{c}1.25 \\
(1.43) \\
{[0.504]}\end{array}$ & $\begin{array}{c}0.917 \\
(1.44) \\
{[0.618]}\end{array}$ & $\begin{array}{l}-9.63 \\
(7.95) \\
{[0.288]}\end{array}$ & $\begin{array}{l}-0.051 \\
(0.105) \\
{[0.632]}\end{array}$ & $\begin{array}{l}-0.603 \\
(0.781) \\
{[0.516]}\end{array}$ \\
\hline \multirow[t]{2}{*}{ Baseline Mean } & $\begin{array}{l}288 \\
0.00\end{array}$ & $\begin{array}{l}288 \\
9.96 \\
\end{array}$ & $\begin{array}{l}288 \\
9.97\end{array}$ & $\begin{array}{l}288 \\
61.7 \\
\end{array}$ & $\begin{array}{c}786 \\
107,881 \mathrm{IDR} \\
\end{array}$ & $\begin{array}{c}288 \\
940,783 \mathrm{IDR}\end{array}$ \\
\hline & $\begin{array}{l}\text { Worksite } \\
\text { Index }\end{array}$ & $\begin{array}{c}\text { No. of } \\
\text { sex workers }\end{array}$ & $\begin{array}{l}\text { No. of } \\
\text { Trans. }\end{array}$ & & Price & $\begin{array}{l}\text { Wkly sex worker } \\
\text { Expenditures }\end{array}$ \\
\hline \multicolumn{7}{|c|}{ C. Client Sample from Client Data } \\
\hline Crim $\times$ Post & $\begin{array}{c}0.070 \\
(0.431) \\
{[0.876]}\end{array}$ & $\begin{array}{c}0.665 \\
(0.925) \\
{[0.822]}\end{array}$ & $\begin{array}{l}-0.536 \\
(0.640) \\
{[0.520]}\end{array}$ & & $\begin{array}{l}-0.092 \\
(0.475) \\
{[0.772]}\end{array}$ & $\begin{array}{c}-0.292 \\
(1.35) \\
{[0.852]}\end{array}$ \\
\hline $\begin{array}{l}\text { Observations } \\
\text { Baseline Mean }\end{array}$ & $\begin{array}{l}593 \\
0.00\end{array}$ & $\begin{array}{l}593 \\
1.48\end{array}$ & $\begin{array}{l}593 \\
1.43\end{array}$ & & $\begin{array}{c}1253 \\
96,620 \mathrm{IDR}\end{array}$ & $\begin{array}{c}593 \\
144,123 \mathrm{IDR}\end{array}$ \\
\hline $\begin{array}{l}\text { Worksite Fixed Effects } \\
\text { Individual Fixed effects } \\
\text { Unit of Observation }\end{array}$ & $\begin{array}{c}\mathrm{Y} \\
\mathrm{N} \\
\text { Individual }\end{array}$ & $\begin{array}{c}\mathrm{Y} \\
\mathrm{N} \\
\text { Individual }\end{array}$ & $\begin{array}{c}\mathrm{Y} \\
\mathrm{N} \\
\text { Individual }\end{array}$ & $\begin{array}{c}\mathrm{Y} \\
\mathrm{N} \\
\text { Individual }\end{array}$ & $\begin{array}{c}\mathrm{N} \\
\mathrm{Y} \\
\text { Transaction }\end{array}$ & $\begin{array}{c}\mathrm{Y} \\
\mathrm{N} \\
\text { Individual }\end{array}$ \\
\hline $\begin{array}{l}\text { Notes. This table reports esti } \\
\text { around the means and standar } \\
\text { of the regressions using the s } \\
\text { "No. of Trans." is the numbe } \\
\text { is the hyperbolic inverse sine } \\
\text { by the sex workers in the pas } \\
\text { client reports visiting in a we } \\
\text { Expenditures" is the hyperbol } \\
\text { those listed for Table II colum } \\
\text { status, years of education, ag } \\
\text { II. Clustered standard errors } \\
\text { errors following Cameron, G } \\
* * * \mathrm{p}<0.01 \text {. }\end{array}$ & $\begin{array}{l}\text { tes of } \beta_{1} \text { from e } \\
\text { leviations of thei } \\
\text { worker data, "N } \\
\mathrm{f} \text { transactions in } \\
\text { insformation of t } \\
\text { even days. For t } \\
\text { "No. of Trans." } \\
\text { inverse sine of th } \\
\text { (2)-(7). See con } \\
\text { discount factor, r } \\
\text { presented in par } \\
\text { ach, and Miller }\end{array}$ & $\begin{array}{l}\text { uation (1). "Worksit } \\
\text { values in criminalize } \\
\text { of Clients" is the } \\
\text { e past seven days, " } \\
\text { transaction price, } \\
\text { outcomes of the re } \\
\mathrm{s} \text { the number of tim } \\
\text { expenditures reporte } \\
\text { ls for Table II colun } \\
\mathrm{k} \text { tolerence, and wo } \\
\text { theses, and wild clu } \\
008) \text {. Standard error }\end{array}$ & $\begin{array}{l}\text { Index" is genera } \\
\text { worksites at bas } \\
\text { umber of paying } \\
\text { lo. of Hrs Worke } \\
\text { d "Weekly Earn } \\
\text { ressions using th } \\
\text { the client repor } \\
\text { by the client for } \\
\text { (8) for controls } \\
\text { site fixed effects } \\
\text { er-bootstrap per }\end{array}$ & $\begin{array}{l}\mathrm{d} \text { from standardizing } \\
\text { ne and taking the un } \\
\text { ients the respondent } \\
\text { "is the reported nun } \\
\text { s" is the hyperbolic } \\
\text { Client data, "No. of } \\
\text { having sex with a s } \\
\text { e past } 7 \text { days. Contr } \\
\text { column (5). Contro } \\
\text { Controls for column } \\
\text { ntile-t p-values are p }\end{array}$ & $\begin{array}{l}\text { ach of the measures } \\
\text { eighted average acro } \\
\text { erviced in the seven } \\
\text { er of hours worked } \\
\text { verse sine transform } \\
\text { ex workers" is the n } \\
\text { worker in the past } \\
\text { in Panel A-B, colun } \\
\text { in Panel C, columns } \\
\text { 6) in Panel C are the } \\
\text { sented in brackets be }\end{array}$ & $\begin{array}{l}\text { columns } 2-4 \text { and column } 6 \\
\text { variables. For the outcomes } \\
\text { ays prior to the survey date, } \\
\text { the past seven days, "Price" } \\
\text { tion of the reported earnings } \\
\text { mber of sex workers that the } \\
\text { days, and "Wkly sex worker } \\
\text { s (1)-(4) and column (6) are } \\
\text { )-(3) and (6) include marital } \\
\text { same as column (8) of Table } \\
\text { ww the conventional standard } \\
\text { alue. * p }<0.10, * * p<0.05 \text {, }\end{array}$ \\
\hline
\end{tabular}




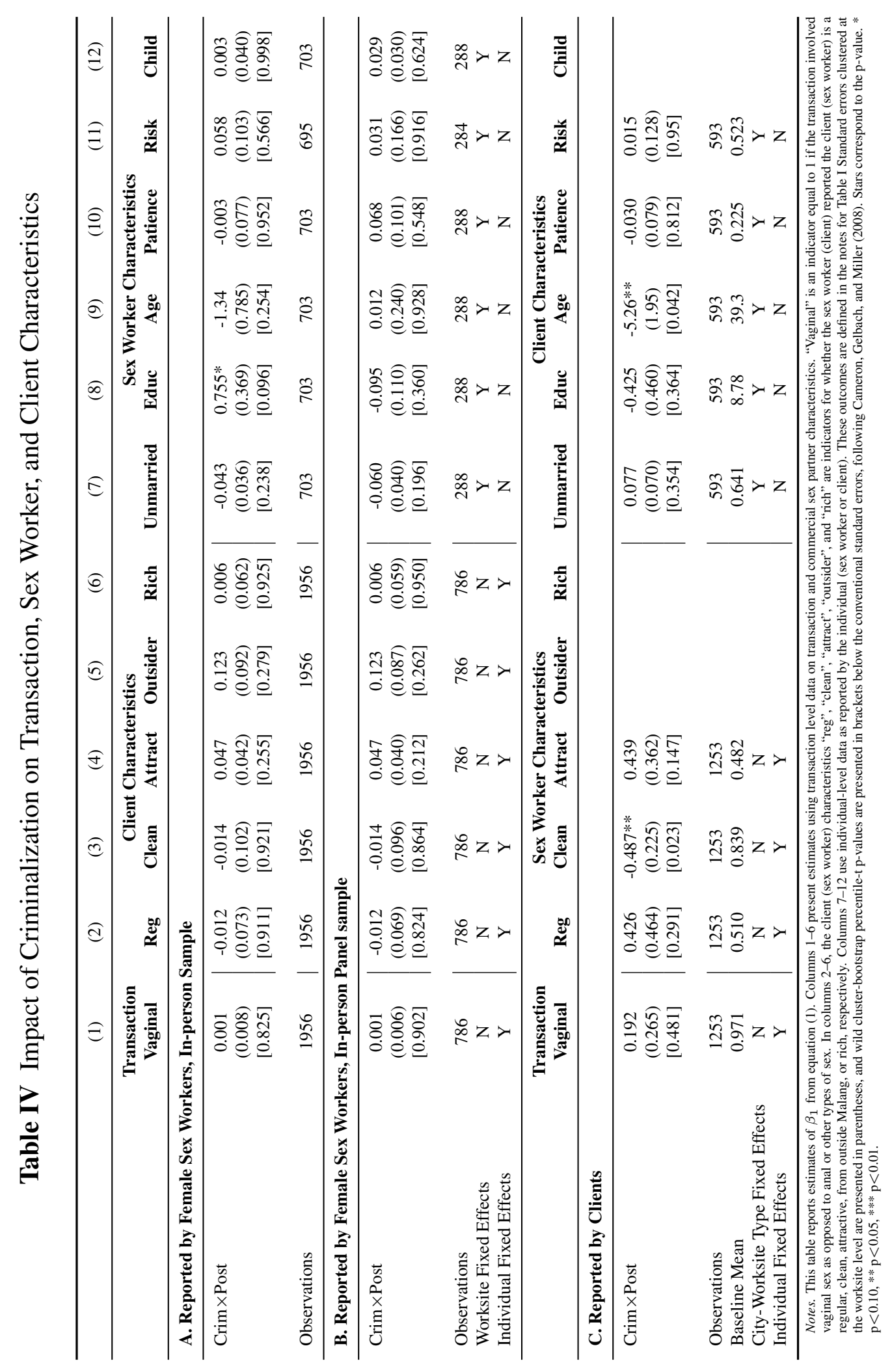


Table V Impact of Criminalization on Earnings, Well-being, and Children

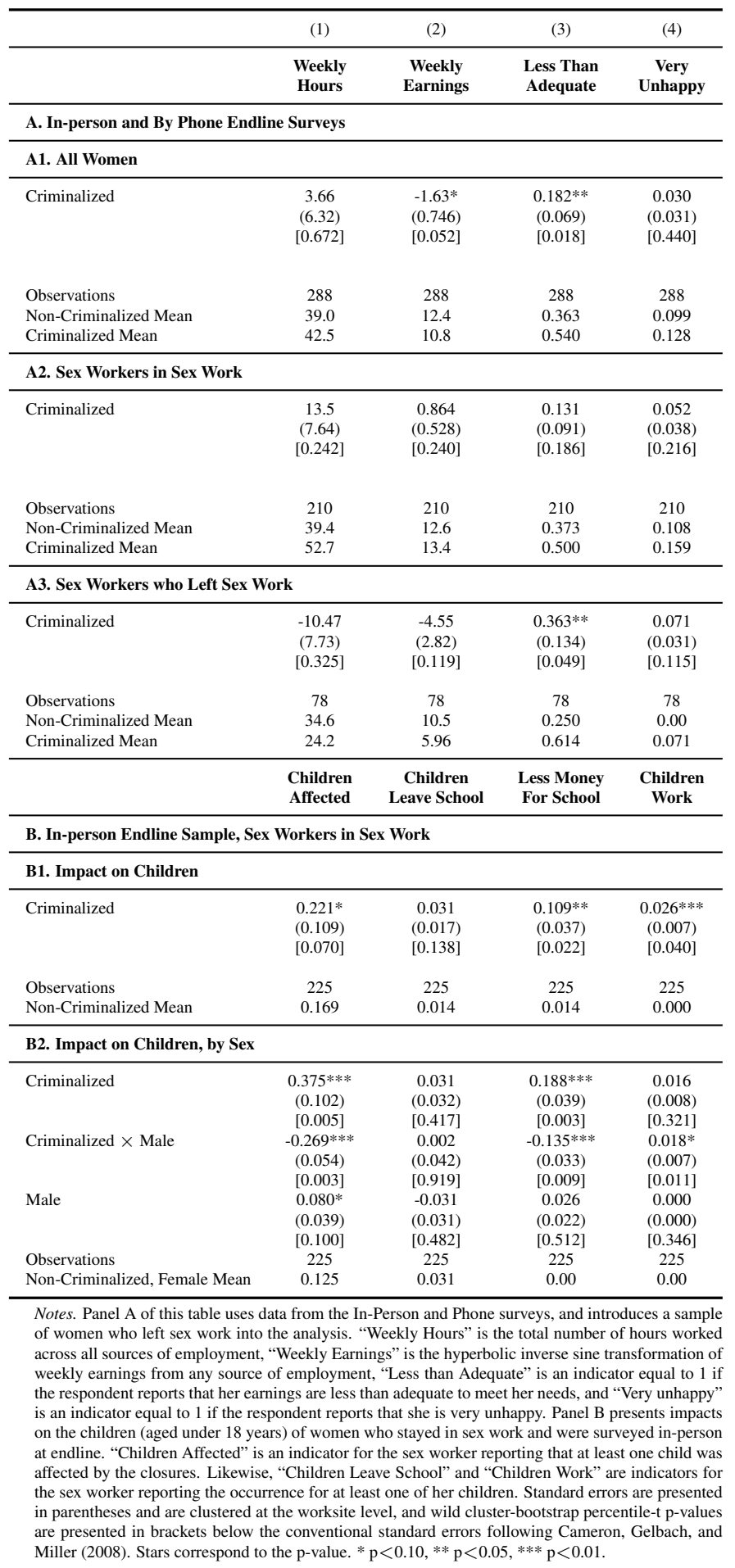


Table VI Impacts on General Population

(1)

(2)

(3)

(4)

Grooming Expenses (IDR) Entertainment Expenses (IDR) Medical Expenses (IDR) STI Symptoms

Panel A: General Population Males

\begin{tabular}{lcccc}
\hline Crim $\times$ Post & $-20188.54^{*}$ & $-42479.17 *$ & -664714.36 \\
$(400758.34)$ & $(0.010$ \\
& $(10421.71)$ & $(21660.39)$ & 387023.68 & 382 \\
Mean & 14656.25 & 19395.83 & 384 & 384 \\
Observations & 384 & & & 15036.28 \\
\hline Panel B: General Population Females & 4043.83 & -8644.23 & $(101776.77)$ & $0.077^{*}$ \\
\hline Crim $\times$ Post & $(11855.12)$ & $(9214.98)$ & 183981.07 & $(0.043)$ \\
\hline Mean & 46005.42 & 5192.31 & 414 & 0.063 \\
Observations & 411 & 416 & 416 \\
\hline
\end{tabular}

Notes. This table presents the results of estimating equation 1 using data collected from males and females living nearby criminalized and non-criminalized worksites in Malang. "Grooming Expenses (IDR)" and "Entertainment Expenses (IDR)"is the amount of money in IDR the respondent spent in the past month on grooming (hairstyle, personal hygiene, make-up) and entertainment, respectively. "Medical Expenses (IDR)" is the amount of money in IDR the respondent spent on medical expenditures (drugs, clinic bill) on self in the past year. "STI Symptoms" is an indicator equal to 1 if the respondent reports having had STI symptoms in the past 3 months. $* \mathrm{p}<0.10, * * \mathrm{p}<0.05, * * * \mathrm{p}<0.01$ 
Table VII Impact of Criminalization on Probability of STI Transmission

(1)

$\%$ Difference

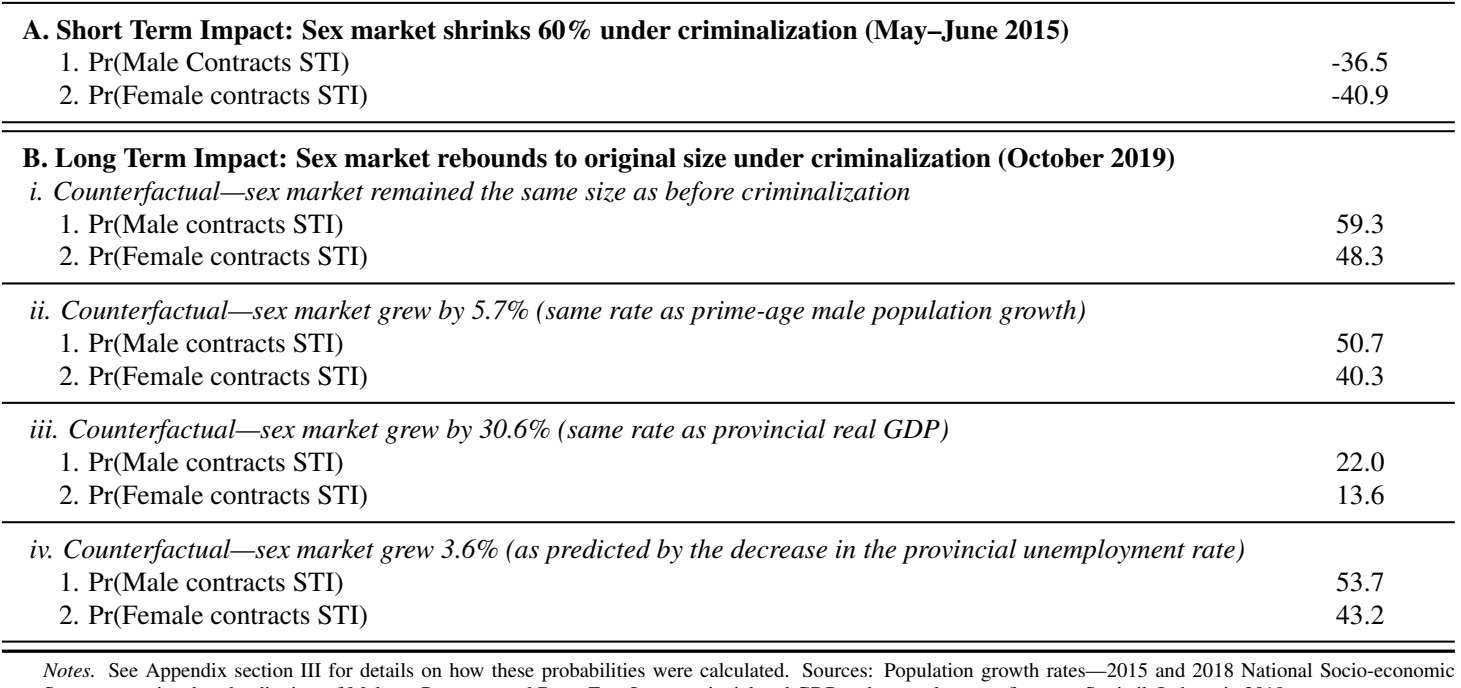
Surveys, restricted to the districts of Malang, Pasuruan and Batu. East Java provincial real GDP and unemployment figures—Statistik Indonesia 2019. 